\title{
Light and productivity of phytoplankton in polar marine ecosystems: a physiological view
}

\author{
EGIL SAKSHAUG and DAG SLAGSTAD
}

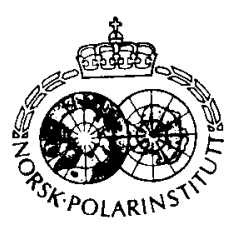

Sakshaug. E. \& Slagstad, D. 1991: Light and productivity of phytoplankton in polar marine ecosystems: a physiological view. Pp. 69-85 in Sakshaug. E., Hopkins, C. C. E. \& Oritsland, N. A. (eds.): Proceedings of the Pro Mare Symposium on Polar Marine Ecology, Trondheim, 12-16 May 1990. Polar Research 10(1).

This study deals with the modelling of photosynthesis and growth of polar phytoplankton and variations in relevant parameters. Polar regions are characterised by low sun elcvations $\left(<40-50^{\circ}\right)$, cxtreme seasonal variations in irradiance and day length, and low sea temperatures $\left(-1.8\right.$ to $\left.6^{\circ} \mathrm{C}\right)$. Due to the latter, maximum phytoplankton growth rates are low $\left(<0.6 \mathrm{~d}^{-1}\right)$.

Light absorption by phytoplankton is strongly dependent on spectral composition (blue oceanic versus green coastal waters), but absorption characteristics (and thus chlorophyll $a$-normalised photosynthetic efficiency $\alpha^{\beta}$ ) do not differ appreciably between polar and other phytoplankton. The maximum chlorophyllnormalised photosynthetic rate $\mathrm{P}_{\mathrm{m}}^{\mathrm{B}}$ is, however, lower and dependent on the irradiance to which the cells are adapted. Chla:C ratios vary widely, but within ranges known for other phytoplankton. The carbonnormalised coefficient $P_{m}^{C}$ varies little with irradiance. but is clearly dependent on day length and nutrient supply. The corresponding coefficient $\alpha^{5}$ is somewhat higher in shade-adapted than in light-adapted cells. Polar species exhibit a high tolerance for strong light and long days in combination with low temperature relative to other species.

The interpretation of P-I functions is discussed, and an empirical formulation is suggested that does not need the Chla:C ratio for predicting the light-limited gross growth rate of polar phytoplankton. Mathematical simulations of the spring bloom indicate that the depth of the mixed layer and the attenuation of light are the most important variables for determining the photosynthetic rate. The spectral composition of light is of particular importance in low light, e.g. in deeply mixed layers. Generally, the deeper the mixing, the more sensitive the development of a spring bloom becomes to any algal or environmental variable.

Egil Sakshaug, Trondhjem Biological Station. The Museum. University of Trondheim, Bynesveien 46, $N$. 7018 Trondheim, Norway; Dag Slagstad, SINTEF, Automatic Control, N.7034 Trondheim-NTH. Norway.

\section{Introduction}

Polar marine environments are characterised by extreme variations in irradiance and day length, and temperature is generally low $\left(-1.8\right.$ to $\left.6^{\circ} \mathrm{C}\right)$. The Arctic seas, including the Bering, Greenland and Norwegian Seas, reach as far south as $60^{\circ} \mathrm{N}$, and the Antarctic Ocean, defined as extending north to the oceanic Polar Front, reaches latitudes as low as $45-50^{\circ} \mathrm{S}$.

Photosynthetic and growth rates of phytoplankton in polar seas may vary significantly because of variations in the light regime, but they are generally low due to low temperature. Phytoplankton is continuously exposed to a light gradient because of variations in atmospheric light and mixing in the water column. Because light is attenuated in water, the depth of the mixed layer and the rate of mixing are essential in controlling the radiation available to algae: the deeper the mixing, the less light on the average is available to the phytoplankton community. In polar areas, blooms may be triggered by the melting of sea ice which leaves phytoplankton suddenly exposed to strong light; a brackish layer which is formed at the same time restricts the depth of mixing. The melting of sea ice thus gives rise to a bloom which trails the receding ice edge and thus occurs later at higher latitudes. This scenario was suggested by Gran (1931). Although such blooms have been observed in all polar seas covered by sea ice [see Sakshaug (1989) for review], they are not easily identified when the ice edge is poorly defined and when ice drifts across nutrient-depleted waters late in the growth season.

The relationship between vertical mixing and the growth of phytoplankton was first proposed by Alexander Nathansohn in 1906 (quoted in Braarud 1935). The relationship was demonstrated by Braarud \& Klem (1931) through comparison of the early blooms in the shallowly mixed Romsdalsfjord in Western Norway with the late blooms in the Norwegian Sea (May-June), and by Riley $(1942 ; 1946)$ at St. Georges Bank. On 
the basis of such observations, Sverdrup (1953) developed a mathematical model in which he introduced the concept of critical depth $\left(z_{c r}\right)$, which is defined as the depth above which depth-integrated photosynthesis equals depth integrated respiration: a bloom develops when vertical mixing is less deep then the critical depth (i.e. the integrated photosynthesis exceeds the integrated respiration). The critical depth may approximately be defined as

$\mathrm{z}_{\mathrm{cr}} \approx \mathrm{P}_{\mathrm{S}} / \mathrm{kr}$

where $P_{S}$ is biomass-specific photosynthetic rate at the surface, $k$ is the vertical attenuation coefficient of light in seawater and $r$ is the biomassspecific respiration rate of algae. It follows that $\mathrm{z}_{\mathrm{cr}}$ becomes large when $\mathrm{P}_{\mathrm{S}}$ is high or $\mathrm{k}$ and $\mathrm{r}$ are low. Sverdrup calibrated his model against data from the weather ship $\mathbf{M}$ in the Norwegian Sea and derived a critical depth that ranged from 30$40 \mathrm{~m}$ in March to $230-280 \mathrm{~m}$ in May.

Sverdrup's model is the backbone of many mathematical models for primary production and may be fairly realistic for predicting the onset of spring blooms. Improvements can be made by including a non-linear relationship between photosynthetic rate and irradiance, the effect of the variable spectral composition of light, and selfshading by phytoplankton. Moreover, although Sverdrup was aware of the importance of losses through, for example, grazing and sedimentation, the model included only the algal dark respiration rate. Unless terms for grazing and sedimentation are included, predicted critical depths may be hundreds of metres in clear waters - far deeper than depths of mixing above which phytoplankton blooms actually occur $(40-80 \mathrm{~m}$, Sakshaug \& Holm-Hansen 1984; Bodungen et al. 1986: Smetacek \& Passow 1990). Finally, algae can adapt to changes in the environment, usually in a fashion that minimises the impact of environmental variation on photosynthetic and growth rates (Sakshaug \& Holm-Hansen 1986). Adaptation changes the values of algal parameters, some of which are essential in dynamical phytoplankton models, e.g. P-I coefficients and the Chlorophyll $a:$ Carbon ratio

The present paper deals with light absorption by polar phytoplankton, mathematical models of photosynthetic and growth rates as well as photoadaptation of polar phytoplankton. The model is examined by analysing recent data from the Barents Sea and comparing observations of spring blooms with predictions. Polar primary production has been reviewed elsewhere (Platt \& Subba Rao 1975; Horner 1976; Alexander 1980; Nemoto \& Harrison 1981; Subba Rao \& Platt 1984) as has the physiological ecology of polar phytoplankton (Jacques 1983; Sakshaug \& HolmHansen 1984; Sakshaug 1989; Smith \& Sakshaug 1990). The photosynthetically relevant aspects of marine optics have been reviewed recently (see Morel 1988; Sathyendranath \& Platt 1989 and references therein; see also Jerlov \& Steemann Nielsen 1974; Jerlov 1976; Tyler 1977; Kirk 1985 for general introduction).

\section{Atmospheric light in polar areas}

Sun elevations are generally low in polar areas. The highest elevation (noon, summer solstice) at $80^{\circ}$ latitude is $33.5^{\circ}$ and at $60^{\circ}$ latitude $53.5^{\circ}$. On the other hand, at latitudes $>66.5^{\circ}$, the sun does not set for part of the summer. Because of this, daily incident irradiance on a cloudless day in midsummer may in fact be higher at high latitudes than in equatorial areas (Campbell \& Aarup 1989).

The diurnal trajectory of the sun is given by

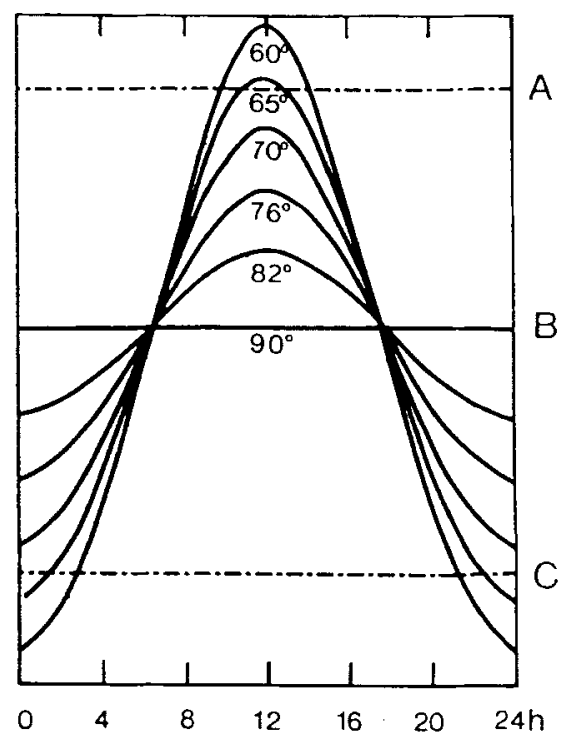

Fig. 1. Diurnal solar trajectory as a function of latitude. The position of the horizon depends on season: $A=$ at summer solstice. $B=$ at equinox, and $C=$ at winter solstice. $A$ and $C$ are $47^{\circ}$ apart. 
latitude only and becomes "flatter" the higher the latitude (see Kirk (1985) for astronomical equations), whereas the horizon may be thought of as moving up or down relative to this trajectory according to the seasons (Fig. 1). The mathematical model by Bird (1984), which predicts spectral scalar irradiance for cloudless days at the sea surface as a function of sun elevation, implies that relative spectral distribution of atmospheric visible light varies little between solar elevations $>10^{\circ}$ (Fig. 2). Predictions from this model also correspond well with data from the Barents Sea in that the highest measured scalar irradiances (PAR, i.e. Photosynthetically Active Radiation, integrated over $400-700 \mathrm{~nm}$ ) at sea surface approximate but do not exceed model predictions (Fig. 3).

Generally, cloud conditions and the wind represent major problems in the modelling of ocean and atmosphere dynamics and thus plankton dynamics. The subarctic region and the mid-tonorthern part of the Antarctic Ocean are, however, in the atmospheric "low pressure belt" in which atmospheric low pressures move incessantly eastwards. This usually yields a weather cycle characterised by $4-6$ cloudy and windy days followed by 1-3 more or less sunny days and less windy days. This induces rhythm in incident light and vertical mixing and is thus of relevance for primary production (Sakshaug et al. 1991b). Because atmospheric low pressures tend to follow the same trajectory for several weeks, cycles of cloudiness and wind may to some extent be reproducible properties of this belt. At high latitudes, in the polar high pressure zone, sunny days may be more frequent but, particularly in the high Arctic, where weather may be calm for extended periods, a thin layer of fog may frequently be formed.

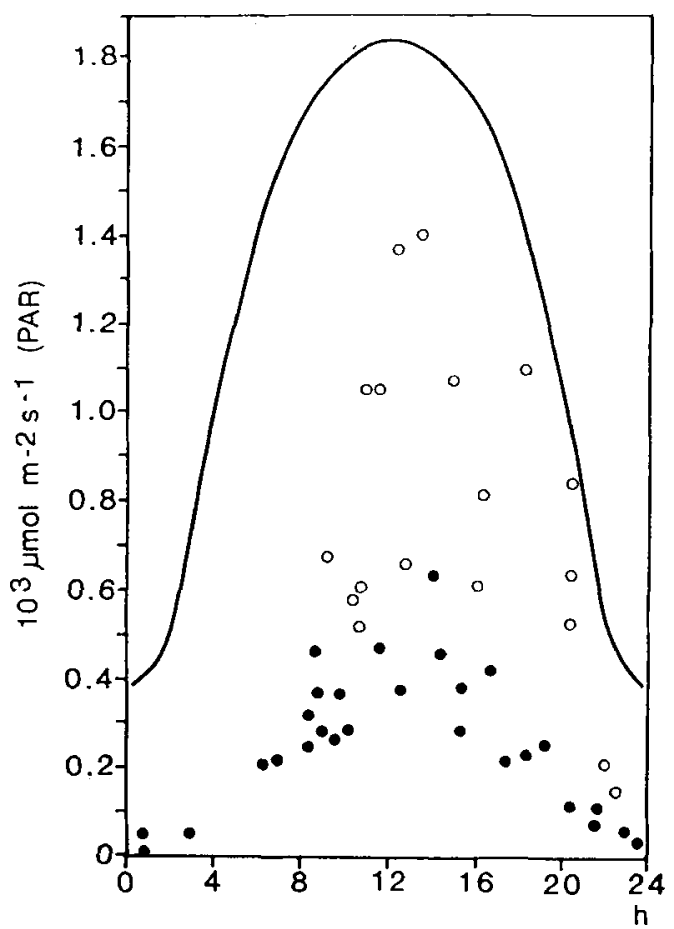

Fig. 3. Scalar irradiance (PAR) at the sea surface on $100 \%$ cloudy days (solid circles) and partly cloudy days (open circles) in the period 25 May- 6 June, 1987 , at $74^{\circ} \mathrm{N}$ in the Barents Sea. Data provided by G. B. Mitchell. The curve represents predictions for a cloudless day (Bird 1984).

Cloud cover and fog may reduce incident light by up to $70-80 \%$ (Kirk 1985). In the southern half of the Barents Sea, the average scalar irradiance (PAR) on fully cloudy summer days is on average only $18 \pm 6 \%$ of the irradiance predicted for a clear day, whereas sunny/partly cloudy days average $55 \pm 20 \%$ (Fig. 2). According to the same set of data, 28 of 46 summer days were fully cloudy, and scalar irradiance (PAR) at $2 \mathrm{~m}$ depth was

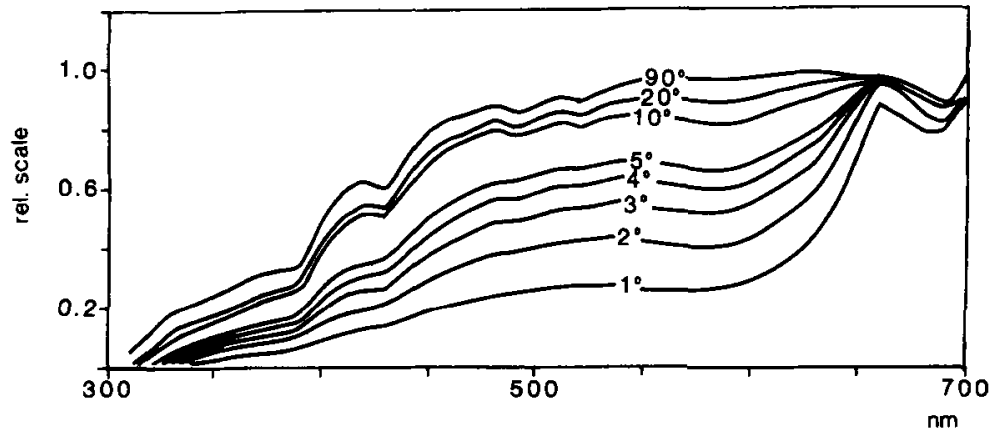

Fig. 2. Spectral distribution of incident light (scalar irradiance, relative scale) at the sea surface on a clear day as a function of sun elevation (after Bird 1984). 
$41 \pm 5 \%$ of scalar irradiance (PAR) at the surface.

\section{Attenuation of light by clear water and sea ice}

In clear oceanic waters, blue rays penetrate the deepest. For "clearest" ocean water (Smith \& Baker 1981), the minimum vertical attenuation coefficient is $0.0168 \mathrm{~m}^{-1}$ at $450 \mathrm{~nm}$ wavelength. while UV $(200 \mathrm{~nm})$ and infrared radiation $(760 \mathrm{~nm})$ have coefficients as high as 3.14 and $2.55 \mathrm{~m}^{-1}$, respectively. Next to blue, ocean water is most transparent to violet and green (Fig. 4).

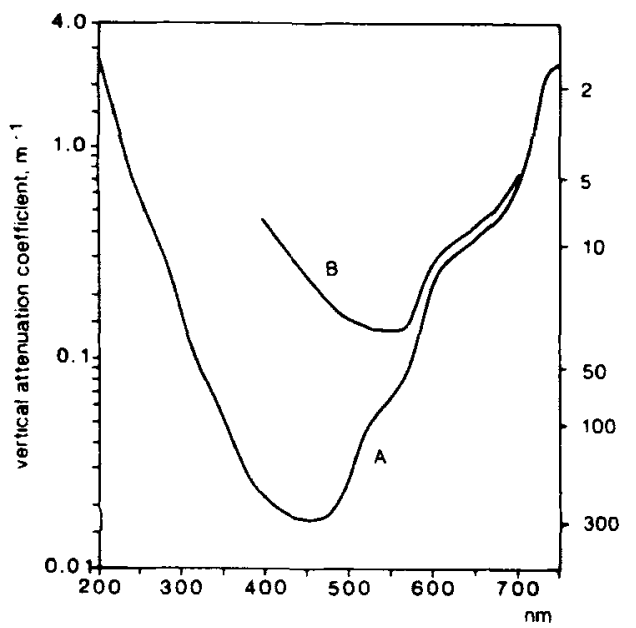

Fig. 4. Vertical diffuse attenuation coefficient of light and $1 c^{\circ}$ light depth in (A) "cleares!" (bluc) ocean water (Smith \& Baker 1981 ) and (B) "clearest" green water in Trondheimsfjorden. Norway, early March (Geir Johnsen. unpubi. data)
Whereas deep-sea polar waters in winter, particularly in the Antarctic Ocean, may be fairly similar to this "clearest" water (Gieskes et al. 1987), waters on shelves and in bays and fjords in northern areas may have minimum attenuation coefficients in the green part of the spectrum $(500-600 \mathrm{~nm})$. Norwegian fjord and Coastal Current waters are, for instance, characterised by input of dissolved yellow matter, mainly of Baltic origin, and therefore strongly absorb blue and violet radiation (Fig. 4). These waters generally have a much higher attenuation coefficient in terms of PAR than the "clearest" blue ocean water (Fig. 4). Because phytoplankton are highly discriminatory with respect to absorption of blue and green light, shifting the spectral distribution of light in water towards green as a bloom develops, the spectral characteristics of seawater are ecologically important (Fig. 5).

Light is greatly attenuated by ice and, in particular, snow. Palmisano et al. (1986) have reported diffuse vertical attenuation coefficients (PAR) of $16-45 \mathrm{~m}^{-1}$ for snow, i.e. a $50 \mathrm{~cm}$ thick layer will only transmit $0.01-3 \%$ of incident light. Sea ice has coefficients of $1.5-1.6 \mathrm{~m}^{-1}$ (PAR) (Maykut \& Grenfell 1975), i.e. a $1 \mathrm{~m}$ thick layer of sea ice will let through about $20 \%$ of incident light. Consequently, ice and its snow cover reduce incident light so much that there is hardly enough for more than algal subsistence below the underside of sea ice.

\section{Absorption of light by particles}

The absorption of light by phytoplankton depends on species size/morphology as well as pigment
Fig. 5. Vertical diffuse attenuation coefficient (PAR) in (A) "clearcst" ocean water and (B) "clearest" Trondheimsfjorden water Same data as in Fig. 4.

\section{$m^{-1}$}

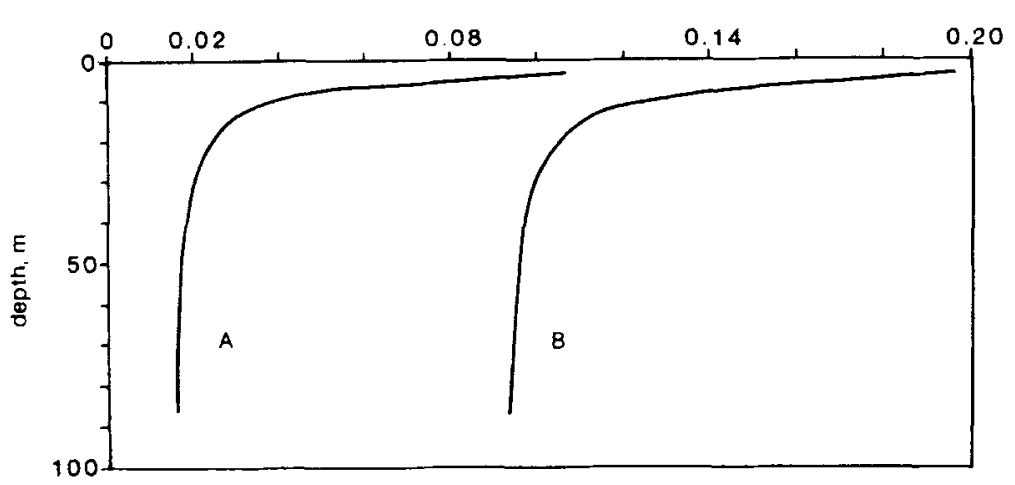


composition, but it is presumably relatively independent of temperature and thus not in principle different for polar and other species (Mitchell \& Kiefer 1988).

The predominant algal species in polar regions have in vivo light absorption spectra which primarily reveal the absorption characteristics of Chlorophyll $a$ (Fig. 6): one major absorption peak at $440 \mathrm{~nm}$, i.e. not far from the wavelength of minimum attenuation in blue water, and one at $675 \mathrm{~nm}$ (red), which is of less ecological relevance since seawater attenuates red light efficiently in the upper few metres. Spectra of the more important groups of polar algae, e.g. diatoms and Phaeocystis pouchetii, exhibit in addition a shoulder caused by fucoxanthin and closely related compounds at about $500 \mathrm{~nm}$, and minor peaks due to Chlorophyll $c$ at 590 and $630 \mathrm{~nm}$ (Fig. 6).

Chlorophyll $a$-specific absorption of light $\left({ }^{\circ} \mathrm{a}_{\mathrm{c}}\right)$ by phytoplankton cultures ranges from 0.0043 0.034 at $676 \mathrm{~nm}$ and $0.004-0.09 \mathrm{~m}^{2}(\mathrm{mg} \mathrm{Chla})^{-1}$ at $440 \mathrm{~nm}$ (Maske \& Haardt 1987). Self-shading in and between chloroplasts may lead to low Chlanormalised absorption by Chla-rich (shadeadapted) cells. This is particularly pronounced in large cells with many chloroplasts (the "package" effect; Kirk 1975; Bricaud et al. 1983; Mitchell \& Kiefer 1988; Berner et al. 1989). Large differences, however, in the absorption of blue light between shade- and light-adapted cells may also be caused by changes in pigment composition (Fig. 4). The "package" effect is pronounced in a Barents Sea clone of the large-celled centric diatom Thalassiosira nordenskioeldii (Fig. 6); e.g. ${ }^{\circ} \mathrm{a}_{\mathrm{c}}$ for red light $(676 \mathrm{~nm})$ is $0.016 \mathrm{~m}^{2}(\mathrm{mg} \mathrm{Chla})^{-1}$ for cells growing at $400 \mu \mathrm{mol} \mathrm{m} \mathrm{m}^{-2} \mathrm{~s}^{-1}$ and 0.0073 for cells growing at $25 \mu \mathrm{mol} \mathrm{m} \mathrm{m}^{-2} \mathrm{~s}^{-1}$. Natural populations in the Barents Sea exhibit the same trend, e.g. ${ }^{\circ} a_{c}(676)$ averages 0.011 in the well-lit upper 10 metres and $0.0057 \mathrm{~m}^{2}(\mathrm{mg} \mathrm{Chl} a)^{-1}$ below $60 \mathrm{~m}$ depth (Table 1 ).

${ }^{\circ} a_{c}$ may overestimate absorption of photosynthetically usable light by algae because some of the absorbed light is unavailable for photosynthesis. This pertains, for instance, to light absorbed by photoprotective pigments such as diadino- and diatoxanthin which do not transfer energy to Photosystem II (Vernet et al. 1989). Chla-normalised absorption of photosynthetically usable light (PUR) may rather be approximated by properly scaled fluorescence excitation spectra $\left({ }^{\circ} \mathrm{F}\right)$, which mimic well the shape of action spectra for oxygen evolution in Photosystem II (Neori et al. 1988). Scaling of relative spectra has until recently been a problem, but can now be easily carried out by use of the dye Basic Blue 3 for quantum correction and matching of the peak at $676 \mathrm{~nm}$ of the corrected spectrum to the cor-
Fig. 6. In vivo Chla-specific light absorption spectra for the large centric diatom Thalassiosira nordenskioeldii (Barents Sea clone) grown at $0.5^{\circ} \mathrm{C}$ and at $400(\mathrm{Tn}-\mathrm{HL})$ and $25 \mu \mathrm{mol} \mathrm{m} \mathrm{m}^{-2} \mathrm{~s}^{-1}$ (Tn-LL). ${ }^{\circ} \mathrm{a}_{\mathrm{c}}$ : total absorption. ${ }^{\circ} \mathrm{F}$ : chlorophyll $a$-fuorescence excitation spectrum (emission $730 \mathrm{~nm}$ ) scaled to ${ }^{\circ} a_{\mathrm{c}}$ at $676 \mathrm{~nm}$ (Sakshaug et al. 1991a).

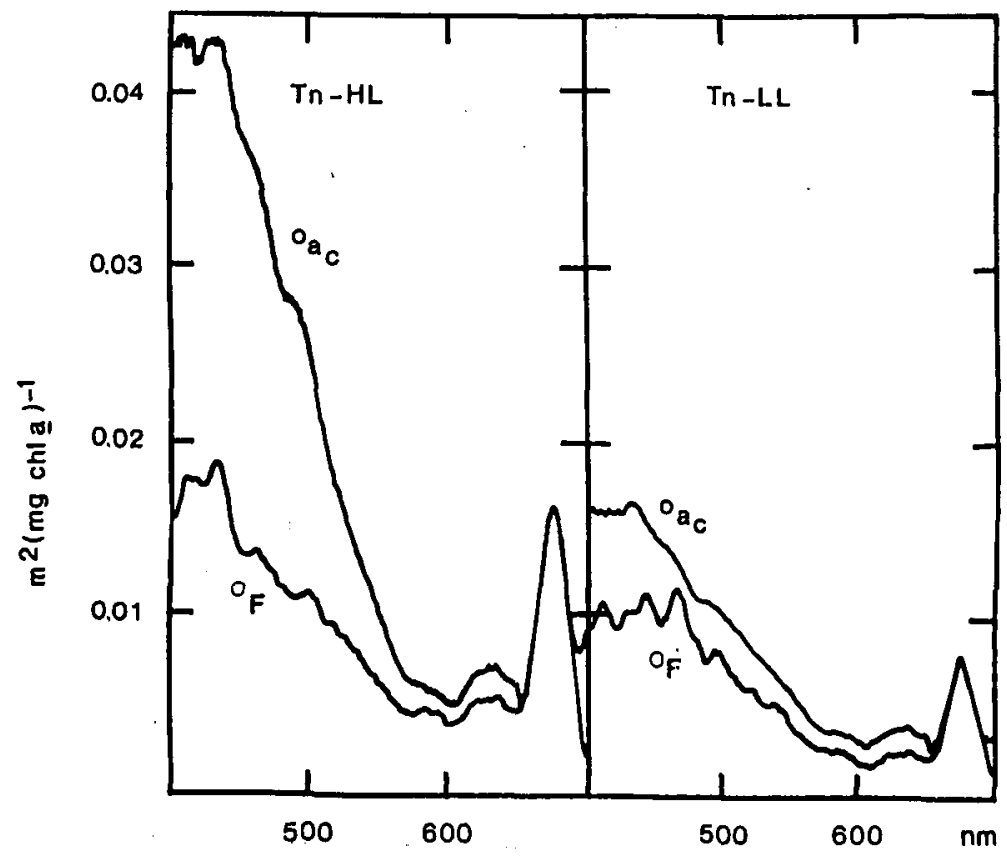


responding peak of ${ }^{\circ} \mathrm{a}_{\mathrm{c}}$ (Kopf \& Heinze 1984; Maske \& Haardt 1987; Sakshaug et al. 1991a). For Thalassiosira nordenskioeldii, ${ }^{\circ} \mathrm{F}$ is 42 and $86 \%$ of ${ }^{\circ} a_{c}$ of light- and shade-adapted cells, respectively, at $440 \mathrm{~nm}$. Hence, ${ }^{\circ} \mathrm{F}$ varies less than ${ }^{\circ} a_{c}$ with photoadaptational status in this species. although it is nevertheless lower for shadeadapted than for light-adapted cells (Fig. 6). The large difference in terms of ${ }^{\circ} \mathrm{a}_{\mathrm{c}}$ between light- and shade-adapted cells in the blue region is presumably in part due to the much higher content of diadino- and diatoxanthin in the former (Sakshaug et al. 1991a) and therefore does not represent a simple "package" effect.

The absorption of light by all particles in the seawater $\left({ }^{*} a_{c}\right)$ can be much larger than ${ }^{\circ} a_{c}$, particularly when the supply of terrigenous material is large (e.g. feeding by glacial rivers), and frequently considerably larger also in offshore areas (Morrow et al. 1989). In the Barents Sea, the difference between ${ }^{*} a_{c}$ and ${ }^{\circ} a_{c}$ is small in the early phase of ice-edge blooms, but becomes larger in the late phase, particularly near the surface (Fig. 7). The difference between ${ }^{*} a_{c}$ and ${ }^{\circ} a_{c}$ in waters with little terrigenous material appears to be caused primarily by pigments which are creamish yellow and insoluble in methanol. Kiefer et al. (1990) have suggested that these pigments are in the main cytochromes, i.e. respiratory enzymes

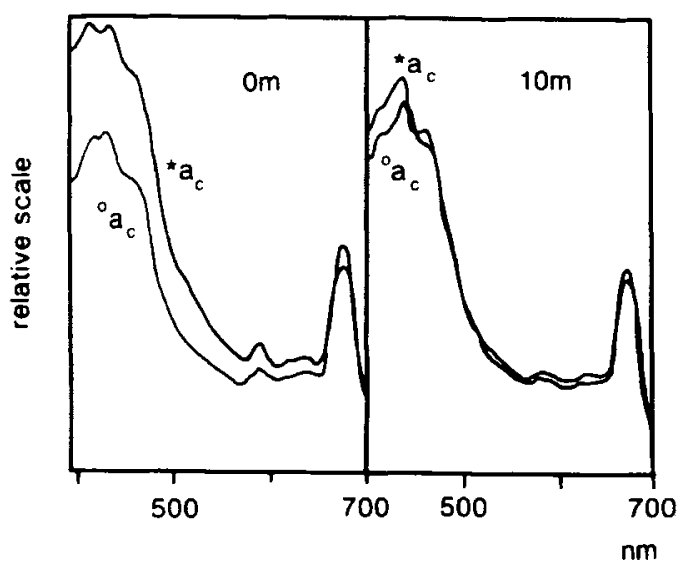

Fig. 7. Examples of Chla-specific absorption of light by particles in the Barents Sea (0 and $10 \mathrm{~m}$ depth, 2 June 1987). ${ }^{*} \mathrm{a}_{\mathrm{c}}=$ total absorption by particles. ${ }^{\circ} \mathrm{a}_{\mathrm{c}}=$ in vivo absorption by chloroplast (methanol-soluble) pigments and their derivatives ( $\mathrm{E}$. Sakshaug, unpubl. data).

present in procaryotes as well as eucaryotes. This raises the possibility that the difference between ${ }^{*} a_{c}$ and ${ }^{\circ} a_{c}$ may be used to estimate respiratory activity in seawater. When phytoplankton stocks are low (e.g. oligotrophic situations), absorption of light by heterotrophs and other non-algal particles may be larger than absorption by chloroplast pigments (Smith et al. 1989).

Table 1 . Averaged photosynthetic parameters ( 24 and $12 \mathrm{~h}$ day length) for Thalassiosira nordenskioeldii and Chaetoceros furcellatus grown at $0.5^{\circ} \mathrm{C}$ and natural populations in the Barents Sea (May-June 1987, 5-25 data sets for each depth range). ${ }^{\circ} \mathrm{F}$ is the integrated value $(400-700 \mathrm{~nm})$ of ${ }^{\circ} \mathrm{F}$ taking the spectral distribution of the illumination into account (calculated in analogy with equation 6). Culture data from Sakshaug et al. (1991a); field data provided by F. Rey. E. Sakshaug, M. Vernet and B. G. Mitchell. For explanation of symbols, see text.

\begin{tabular}{|c|c|c|c|c|c|}
\hline & Cultures & & \multicolumn{3}{|c|}{ Barents Sea } \\
\hline & $\mu \mathrm{mol} \mathrm{m} \mathrm{m}^{-2} \mathrm{~s}^{-1}$ & & \multicolumn{3}{|c|}{ Depth, $m$} \\
\hline & 400 & 25 & $0-20$ & $30-60$ & $>70$ \\
\hline${ }^{\prime} \alpha^{8}$ & 0.025 & 0.023 & 0.026 & 0.025 & 0.020 \\
\hline $2 \mathrm{P}_{\mathrm{m}}^{\mathrm{B}}$ & 1.7 & 0.8 & 1.6 & 1.3 & 0.9 \\
\hline${ }^{3} \mathrm{I}_{\mathrm{k}}$ & 68 & 35 & 63 & 52 & 46 \\
\hline${ }^{40} a_{c}(676)$ & 0.024 & 0.014 & 0.011 & 0.0094 & 0.0057 \\
\hline${ }^{10} \mathrm{~F}$ & 0.011 & 0.0078 & & & \\
\hline q $q$ & 405 & 1080 & & & \\
\hline${ }^{n} \varphi_{\text {mux }}$ & 0.058 & 0.070 & & & \\
\hline t. $\phi_{\operatorname{mix}}$ & 0.045 & 0.035 & & & \\
\hline
\end{tabular}

\footnotetext{
${ }^{1} \mathrm{mgC}(\mathrm{mgChia})^{-1} \mathrm{~h}^{-1}\left(\mu \mathrm{mol} \mathrm{m}{ }^{-2} \mathrm{~s}^{-1}\right)^{-1}$

$\therefore \mathrm{mgC}(\mathrm{mgChia})^{-1} \mathrm{~h}^{-1}$

3 umol $\mathrm{m}^{-2} \mathrm{~s}^{-1}$

+ $\mathrm{m}^{2}$ (mg Chla)

s mg Chla (mol PSU) ${ }^{-1}$

${ }^{\circ} \mathrm{g}$-at C $(\mathrm{mol})^{-1}$

growth-normalised values
} 


\section{P-I functions}

P-I functions describe the photosynthetic response of phytoplankton to irradiance. The simplest formulation is a straight line:

$\mathrm{P}=\alpha \mathrm{E}_{\mathrm{o}}$

where $\mathrm{P}$ is biomass-normalised carbon uptake (or oxygen evolution), $\mathrm{E}_{\mathrm{o}}$ is irradiance, and $\alpha$ is the slope of the line. This linear relationship was used in Sverdrup's (1953) model. Because, however, the quantum yield of photosynthesis decreases with increasing irradiance, the photosynthetic rate in reality forms a saturation function with irradiance. Equation 2 is therefore adequate only at very low irradiances. An empirical and simple saturation function (Fig. 8) was suggested by Webb et al. (1974):

$\mathrm{P}^{\mathrm{B}}=\mathrm{P}_{\mathrm{m}}^{\mathrm{B}}\left[1-\exp \left(-\alpha^{\mathrm{B}} \mathrm{E}_{\mathrm{o}} / \mathrm{P}_{\mathrm{m}}^{\mathrm{B}}\right)\right]$

where $\mathbf{P}^{\mathrm{B}}$ is chlorophyll-normalised carbon uptake [mg C (mg Chla $\left.)^{-1} \mathrm{~h}^{-1}\right], \mathrm{P}_{\mathrm{m}}^{\mathrm{B}}$ is maximum carbon uptake, $\mathrm{E}_{\mathrm{o}}$ is in $\mu \mathrm{mol} \mathrm{m} \mathrm{m}^{-2} \mathrm{~s}^{-1}$, and $\alpha^{B}$ is the slope of the curve at the origin [mg C (mg $\left.\mathrm{Chl} a)^{-1} \mathrm{~h}^{-1} \mathrm{E}_{\mathrm{o}}^{-1}\right]$. The ratio $\mathrm{P}_{\mathrm{m}}^{\mathrm{B}} / \alpha^{\mathrm{B}}$, the light saturation index, is termed $I_{k}$.

An alternative formulation for equation 3 based on target theory (Arnold 1932; Myers \& Graham 1971; Ley \& Mauzerall 1982; Dubinsky et al. 1986) has been suggested by Sakshaug et al. (1991a). This formulation makes the physiologically relevant coefficients explicit (Fig. 8):

$\mathrm{P}^{\mathrm{B}}=\left(\phi_{\max } / \mathrm{q} \tau\right)\left[1-\exp \left(-{ }^{\circ} \sigma \mathrm{q} \tau \mathrm{E}_{\mathrm{o}}\right)\right]$.
In equation 4 , the system of units conveniently differs from that of equation $3: \mathrm{P}^{\mathrm{B}}$ is in g-at $\mathrm{C}(\mathrm{mg}$ $\mathrm{Chl} a)^{-1} \mathrm{~h}^{-1}$ and $\mathrm{E}_{\mathrm{o}}$ in mol m $\mathrm{m}^{-2} \mathrm{~h}^{-1}$. ${ }^{\circ} \sigma$ is the Chlanormalised specific absorption of photosynthetically usable light $\left[\mathrm{m}^{2}(\mathrm{mg} \mathrm{Chla})^{-1}\right]$; the scaled fluorescence excitation spectrum ${ }^{\circ} \mathrm{F}$ may be used as an adequate approximation (Sakshaug et al. 1991a). $\tau$ is the minimum turnover time for electrons in the photosystems (h), and $q$ is the amount of Chla per photosynthetic unit [mg Chla $(\mathrm{mol}$ PSU $)^{-1}$ ]. The PSU is here functionally defined, e.g. the existence of different photosystems is disregarded - $q \tau$ probably mainly represents properties of PSII. $\phi_{\max }$, the maximum quantum yield, converts photons to carbon [ $\mathrm{g}$-at $\mathrm{C}$ ( $\mathrm{mol}$ photons $)^{-1}$ ] or oxygen [ $\mathrm{mol} \mathrm{O}_{2}$ (mol photons) $\left.{ }^{-1}\right]$.

Equation 4 is the product of a linear function for photosynthesis versus irradiance multiplied by the Poisson Probability (PP) for a photon to hit a photosynthetic unit with an open reaction centre (i.e. the quantum efficiency). The latter term has the value 1 for zero light and the value zero for infinite irradiance:

$$
\begin{aligned}
\mathrm{P}^{\mathrm{B}}= & \left(\phi_{\max }{ }^{\mathrm{o}} \sigma \mathrm{E}_{\mathrm{o}}\right) \\
& (\text { linear }) \\
& \times\left[1-\exp \left(-{ }^{\circ} \sigma \mathrm{q} \tau \mathrm{E}_{\mathrm{o}}\right)\right] /{ }^{\circ} \sigma \mathrm{q} \tau \mathrm{E}_{\mathrm{o}}
\end{aligned}
$$

When multiplied by $\phi_{\max }$, the Poisson Probability term predicts the quantum yield.

Equations 3 and 4 are mathematically equivalent, thus $\alpha^{\mathrm{B}}=43.2 \phi_{\max }{ }^{\circ} \sigma, \mathrm{P}_{\mathrm{m}}^{\mathrm{B}}=12000 \mathrm{P}_{\mathrm{m}}^{\mathrm{B}} / \mathrm{q} \tau$, and $I_{k}=278 /{ }^{\circ} \sigma q \tau$. It should be noted that $P_{m}^{B}$ and
Fig. 8. P-I curve according to Webb et al. (1974) and target theory notation (Sakshaug et al. 1991a). Because of ${ }^{\circ} \sigma$, values for $\alpha^{\theta}$ and $I_{k}$ depend on the spectral distribution of the light.

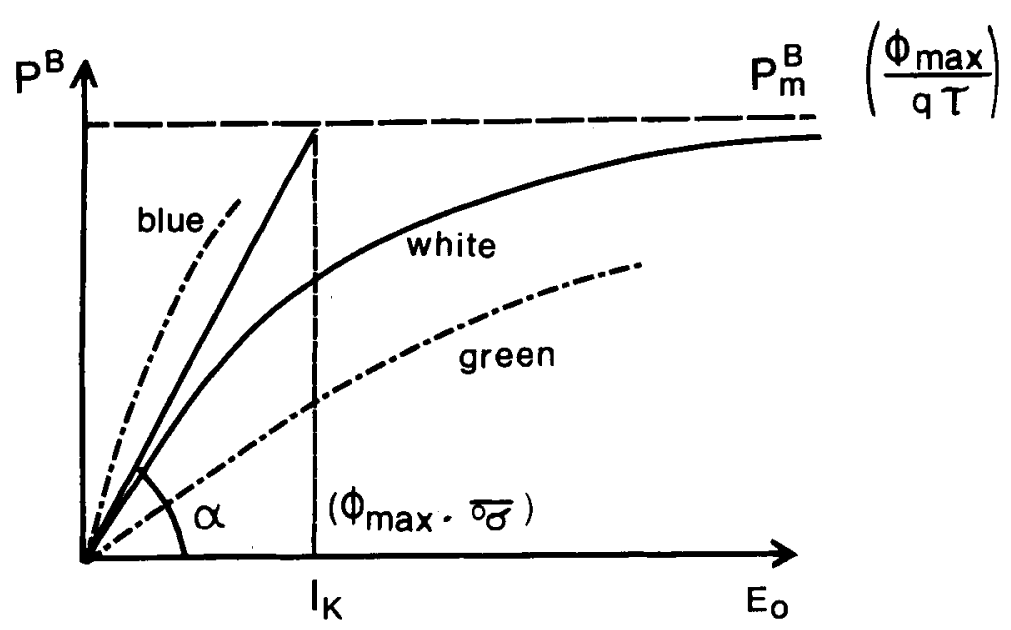




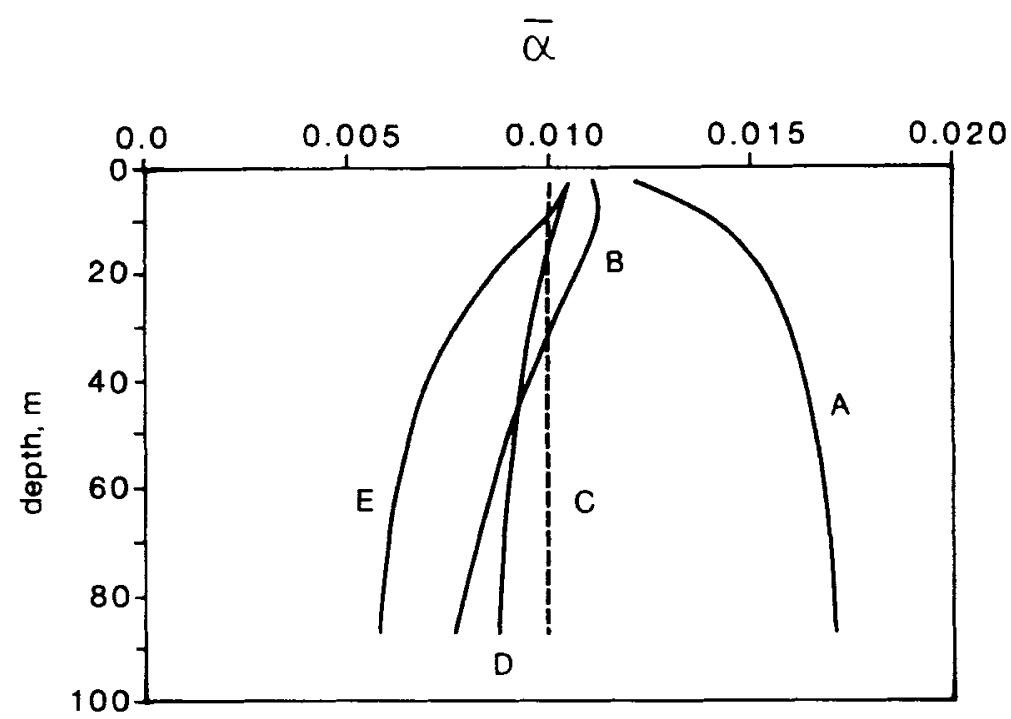

Fig. 9. Variations in the integrated $(400-700 \mathrm{~nm})$ value $\alpha^{\beta}$ as a function of changes in spectral distribution of light with depth (infinitesimal chlorophyll concentration assumed for $A$ and $B$ ): $A=$ "clearest" ocean water (Fig. 4): $\mathrm{B}=$ "clearest" Trondheimsfjorden water (Fig. 4): $\mathrm{C}=$ "white" halogen lamp (Osram HQl 250):

$\mathrm{D}=$ "clearest" blue water with

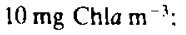

$E=$ "clearest" blue water with

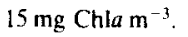

$\alpha^{B}$ include the conversion factor $\phi_{\max }$ whereas $I_{k}$ does not and that $\mathrm{P}_{\mathrm{m}}^{\mathrm{B}}$ is spectrally independent in accordance with experimental data (Rochet et al. 1986).

Because $\alpha^{B}$ and $I_{k}$ include the spectrum ${ }^{\circ} \sigma$, they depend on the spectral distribution of ambient light. If ${ }^{\circ} \sigma$ (e.g. ${ }^{\circ} \mathrm{F}$ ) and $\alpha^{B}$ for the P-I incubator light source is known, the integrated value $a^{B}$ $(400-700 \mathrm{~nm})$ for a particular submarine light regime can be calculated if the spectral distribution of that light is known (Morel 1978; Lewis et al. 1985: SooHoo et al. 1987):

$$
\begin{aligned}
\overline{\alpha^{\mathrm{B}}} & =43.2 \phi_{\max } \overline{{ }^{\circ}} \sigma=43.2 \phi_{\max } \\
& \left.\times\left[\int_{4(0) \mathrm{nm}}^{7(\kappa) \mathrm{nm}} \sigma(\lambda) \mathrm{E}_{0} \mathrm{~d} \lambda\right] / \mathrm{E}_{0}(\text { PAR })\right] .
\end{aligned}
$$

$E_{0}(\lambda)$ is the spectral irradiance of the particular light regime and $E_{0}(P A R)$ the integrated (400$700 \mathrm{~nm})$ irradiance for the P-I incubator. Equation 6 implies that $\alpha^{B}$ derived on the basis of a "white" incubator light source may differ from the value $a^{B}$ relevant in the field (Fig. 8). Assuming an infinitesimally small phytoplankton stock, $\alpha^{B}$ may increase with depth by a factor $>2$ in blue oceanic waters because the water becomes "bluer" (Fig. 9). In green waters the converse takes place. When phytoplankton bloom, blue radiation is more rapidly absorbed by algae. so

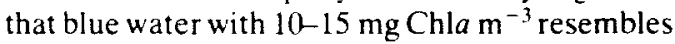
green water optically. This has the additional implication that, unless special correction algor- ithms are employed, satellite images of chlorophyll in the sea may considerably overestimate phytoplankton stocks in humus-laden waters, such as along the Norwegian coast.

\section{Variations in P-I coefficients}

P-I coefficients are adaptive parameters, i.e. their values may change as a response to the environment in which the algae have been growing. The rate of adaptation depends on the coefficient in question, but data are sparse and do not form a general pattern (Gallegos et al. 1983; Post et al. 1984: Sakshaug et al. 1987; Cullen \& Lewis 1988; Hegseth 1989). Changes in the Chla:C ratio may be completed in a matter of a few hours to some days. P-I coefficients may change in the course of $<30$ minutes (Lewis \& Smith 1983; Legendre et al. 1988); therefore. functions other than 3 and 4 may correspond better with the data if incubation time is longer than this (Jassby \& Platt 1976; Platt et al. 1980; Leverenz 1988). Day length and nutrient supply apparently affect Chla-normalised P-I coefficients little compared to irradiance, although this may be species-dependent (Sakshaug et al. 1989: 1991a).

$a^{B} \cdot P_{m}^{B}$ and $I_{k}$ of polar phytoplankton exhibit a bewildering variability (see Harrison \& Platt 1980: 1986: Smith \& Sakshaug 1990 and references therein). Reported values for $\alpha^{B}$ in white light range from $0.001-1 \mathrm{mg} \mathrm{C}(\mathrm{mg} \mathrm{Chla})^{-1} \mathrm{~h}^{-1}$ 
$\left(\mu \mathrm{mol} \mathrm{m} \mathrm{m}^{-2} \mathrm{~s}^{-1}\right)^{-1}$ and for $\mathrm{P}_{\mathrm{m}}^{\mathrm{B}}$ from $0.1-15 \mathrm{mg} \mathrm{C}$ $(\mathrm{mg} \mathrm{Chl} a)^{-1}$. The majority of values for $\alpha^{\mathrm{B}}$, however, range from $0.010-0.030$ and for $\mathrm{P}_{\mathrm{m}}^{\mathrm{B}}$ from 0.3-2.0. Also $\mathrm{I}_{\mathrm{k}}$ exhibits a pronounced variability: $0.5-700 \mu \mathrm{mol} \mathrm{m} \mathrm{m}^{-2} \mathrm{~s}^{-1}$ has been reported although the majority of values lie between 30 and $200 \mu \mathrm{mol} \mathrm{m} \mathrm{m}^{-2} \mathrm{~s}^{-1}$. Some values, particularly the extreme ones, may be erroneous due to problems in measuring carbon uptake and Chla and extensive manipulation of the samples before incubation (including shocks caused by strong light, and in the special case of ice algae: caused by melting).

Data sets may be difficult to compare because of differences in methodology: incubation time and time of day may be significant (Smith \& Lewis 1983; Legendre et al. 1988), the spectral composition of incubator lamps may differ, and whereas some data sets are based on filtration of samples after incubation, others are not. Finally, species composition of communities may play a role. Adaptive variation in natural communities may therefore be difficult to distinguish from variations caused by other sources.

$\phi_{\max }$, which is included in both $\mathrm{P}_{\mathrm{m}}^{\mathrm{B}}$ and $\alpha^{\mathrm{B}}$, cannot be measured directly and is therefore a residual in regressions. It thus "absorbs" systematical errors, and, more important, it depends on how much of the flow of fixed energy through the cells is intercepted by the method for measuring photosynthesis. Measurement of oxygen release - which takes place in Photosystem II and therefore before any fixed energy is spent by dark reactions - may yield values close to the theoretical maximum $\left[0.125 \mathrm{~mol} \quad \mathrm{O}_{2} \quad\right.$ (mol photons $)^{-1}$; carbon uptake does not, because a fraction of the supplied energy is spent on uptake of nutrients instead of the uptake of carbon. Typical values for carbon uptake (unfiltered samples) are $0.07-0.08 \mathrm{~g}$-at $\mathrm{C}$ (mol photons) ${ }^{-1}$ (Langdon 1988). Moreover, estimates of carbon uptake based on filtered samples (e.g. growth-relevant estimates) yield values as low as $0.04-0.06 \mathrm{~g}$-at $\mathrm{C}$ (mol photons) $)^{-1}$, in part because they do not include production of extracellular carbon (Ziemann et al. 1987; Sakshaug et al. 1991a). Some low values for $\phi_{\max }$ have been reported because they have been calculated as $\alpha^{B} /{ }^{\circ} a_{c}$ instead of $\alpha^{\mathrm{B} /{ }^{\circ}} \mathrm{F}$. For light-adapted cells the difference can be considerable (e.g. $\approx 50 \%$ ).

$\alpha^{B}$ of Arctic phytoplankton may be equal or somewhat lower for shade-adapted than for lightadapted algae (Platt et al. 1982); this is pre- sumably related to a low value for ${ }^{\circ} \mathrm{F}$ in shadeadapted algae. Moreover, data sets from northern areas exhibit a clear positive covariation between $\alpha^{B}$ and $\mathrm{P}_{\mathrm{m}}^{\mathrm{B}}$ (Harrison \& Platt 1980; 1986). A physiological reason for this covariation may be the concomitant lowering and raising of ${ }^{\circ} \mathrm{F}$ and the product $q \tau$, respectively, when light-adapted cells become shade-adapted (Table 1). Variability in $\phi_{\max }$ will also cause $\mathrm{P}_{\mathrm{m}}^{\mathrm{B}}$ and $\alpha^{\mathrm{B}}$ to covary.

$\phi_{\max }$ and ${ }^{\circ} \mathrm{F}$ put constraints on the variation in $\alpha^{B}$. For white light, ${ }^{\circ} \mathrm{F}$ is hardly higher than 0.004 $0.015 \mathrm{~m}^{2}$ (Chla) $^{-1}$ (Sakshaug et al. 1991a). This value and the theoretical maximum of 0.125 for $\phi_{\max }$ imply an upper limit of $0.08 \mathrm{mg} \mathrm{C}(\mathrm{mg}$ Chla $)^{-1} \mathrm{~h}^{-1}\left(\mu \mathrm{mol} \mathrm{m}{ }^{-2} \mathrm{~s}^{-1}\right)^{-1}$ for $\alpha^{\mathrm{B}}$. For total carbon uptake, $\alpha^{B}$ is likely to be lower than 0.05 , whereas $\alpha^{B}$ for filtered samples (the majority of published data) may be as low as 0.025-0.040. Assuming a minimum value for ${ }^{\circ} \mathrm{F}$ of $0.004 \mathrm{~m}^{2}(\mathrm{mg}$ $\mathrm{Chl} a)^{-1}$, the lower limit for $\alpha^{\mathrm{B}}$ (filtered samples) becomes 0.007 . The large majority of reported values for $\alpha^{B}$ of polar phytoplankton are actually between 0.007 and 0.040 .

The Chla:C ratio varies inversely with irradiance and day length and proportionally with nutrient supply (Sakshaug \& Andresen 1986). Therefore the patterns of variation for the carbonnormalised $\mathrm{P}$-I coefficients $\mathrm{P}_{\mathrm{m}}^{\mathrm{C}}$ and $\alpha^{\mathrm{C}}$ (i.e. $\mathrm{P}_{\mathrm{m}}^{\mathrm{B}}$ and $\alpha^{\mathrm{B}}$, respectively, multiplied by the Chla:C ratio) differ from those of $\mathrm{P}_{\mathrm{m}}^{\mathrm{B}}$ and $\alpha^{\mathrm{B}}$. In fact, $\mathrm{P}_{\mathrm{m}}^{\mathrm{C}}$, the maximum hourly carbon turnover rate, appears to be relatively independent of irradiance (Sakshaug \& Holm-Hansen 1986) but strongly dependent on day length (Table 2) and nutrient status (Sakshaug et al. 1989). $\alpha^{\mathrm{C}}$ appears to increase somewhat when cells become adapted to low irradiance and short days, largely because ${ }^{\circ} \mathrm{F}$ decreases less than the Chla:C ratio increases (Sakshaug \& Holm-Hansen 1986; Sakshaug 1989). Thus shade-adapted cells are photosynthetically more efficient than light-adapted cells, in spite of the opposite impression given by variations in $\alpha^{B}$.

\section{Light-limited growth rates}

Reported growth rates of polar phytoplankton are up to $1.7 \mathrm{~d}^{-1}$ [see Smith \& Sakshaug (1990) for review]; long-term studies (several days) of shipboard cultures, however, indicate maximum rates of $0.35-0.90 \mathrm{~d}^{-1}$ at $<5^{\circ} \mathrm{C}$ (Sakshaug \& Holm-Hansen 1986; Wilson et al. 1986; Spies 
1987). The maximum growth rate among cultures of 10 diatoms from the Barents Sea grown at $-0.5^{\circ} \mathrm{C}$ was $0.64 \mathrm{~d}^{-1}$, and the average maximum for the ten species was $0.52 \mathrm{~d}^{-1}$ (Gilstad \& Sakshaug 1990). The function by Eppley (1972), which predicts the maximum temperature-dependent growth rate among numerous temperate species grown in laboratory cultures at $>2^{\circ} \mathrm{C}$, predicts by extrapolation a maximum growth rate of $0.55 \mathrm{~d}^{-1}$ at $0^{\circ} \mathrm{C}$. It thus seems that maximum growth rates of polar phytoplankton on the average are not higher than those that would be exhibited by temperate species at low temperatures.

Experiments with shipboard cultures of natural communities (Sakshaug \& Holm-Hansen 1986; Sakshaug 1989) indicate an optimum range of 35$105 \mu \mathrm{mol} \mathrm{m} \mathrm{m}^{-2} \mathrm{~s}^{-1}$ for Antarctic ice-edge communities, yielding a growth rate of $0.25 \mathrm{~d}^{-1}$, and $100-250 \mu \mathrm{mol} \mathrm{m} \mathrm{m}^{-2} \mathrm{~s}^{-1}$ for a Barents Sea plankton community, yielding a growth rate of $0.46 \mathrm{~d}^{-1}$ (Syvertsen, Holm-Hansen and Sakshaug quoted in Sakshaug 1989). Gilstad \& Sakshaug (1990) reported a wider optimum range (70 to 330$500 \mu \mathrm{mol} \mathrm{m} \mathrm{m}^{-2} \mathrm{~s}^{-1}$ ) for cultures of Barents Sea diatoms and a strong dependence of growth rate on day length.

The growth rate is a function of the difference between gross particulate production rate and cellular loss rates (respiration, extracellular production). It is thus a function of rates which themselves are composite functions of environmental variables. The $Q_{10}$ value of polar phytoplankton for dark respiration (i.e. the factorial increase due to a temperature increase of $10^{\circ} \mathrm{C}$ ) is apparently higher (2.3-12) than that for gross photosynthesis (1.4-2.2; Neori \& Holm-Hansen 1982; Tilzer \& Dubinsky 1987). Thus a small temperature change may affect the growth rate considerably by altering the respiration rate. Respiration rates also tend to increase adaptively with increasing irradiance (Falkowski \& Owens 1980; Langdon 1988; Sakshaug et al. 1991a) and may be higher during light hours than dark hours (Weger et al. 1989).

The steady-state gross growth rate $\mu+\mathrm{r}\left(\mathrm{d}^{-1}\right)$ of phytoplankton, where $r$ is the daily carbonspecific respiration rate (and in principle includes extracellular production), may be modelled (Bannister \& Laws 1980; Sakshaug et al. 1989; Cullen 1990):

$\mu+\mathrm{r}=(\mathrm{Chl} a: \mathrm{C}) \cdot \mathrm{D} \cdot \mathrm{BP}^{\mathrm{B}}=\mathrm{BP}^{\mathrm{C}} \cdot \mathrm{D}$

In this empirical formulation, $\mathrm{g}^{\mathrm{B}}$ may represent equations 3 or 4 with growth-normalised coefficient values, and the Chla:C ratio, accordingly, is in either $\mathrm{mg} \mathrm{mg}^{-1}$ or $\mathrm{mg}(\mathrm{g}-\mathrm{at})^{-1}$, and $\mathrm{D}$ is day length $(h)$. Because growth-relevant carbon represents a fraction of the total fixed carbon, whereas the growth rate is an integrated feature over $24 \mathrm{~h}$ and P-I coefficients may vary somewhat diurnally, ${ }^{8} P^{B}$ may differ from $P^{B}$ of $P-I$ curves. Sakshaug et al. (1991a) have suggested that $\phi_{\max }$ in equation 4 may be adjusted to a growth-relevant value ${ }^{g} \phi_{\max }$, the other coefficients being retained. For equation 3 this implies a pro rata adjustment of $\alpha^{\mathrm{B}}$ and $\mathrm{P}_{\mathrm{m}}^{\mathrm{B}}$ to growth-relevant values ${ }^{g} \boldsymbol{\alpha}$ and ${ }^{g} P_{\mathrm{m}}^{B}$, respectively, whereas $I_{k}$ is retained:

$$
\begin{aligned}
& \mu+\mathrm{r}=(\text { Chla:C }) \cdot \mathrm{D} \cdot\left({ }^{\mathrm{g}} \phi_{\max } / \mathrm{q} \tau\right) \\
& \quad \times\left[1-\exp \left(-{ }^{\circ} \sigma q \tau \mathrm{E}_{\mathrm{o}}\right)\right]
\end{aligned}
$$

Table 2. Chla: $\mathrm{C}$ ratio $\left(\mathrm{mg} \mathrm{mg}^{-1}\right)$ and the product $\mathrm{P}_{\mathrm{m}}^{\mathrm{B}}(\mathrm{Chla}: \mathrm{C}), \mathrm{h}^{-1}\left(=\mathrm{P}_{\mathrm{m}}^{\mathrm{C}}\right)$ for cultures and natural populations in the Barents Sea. The upper mixed layer, when thin. may have $\mathrm{Chla}: \mathrm{C}$ ratios $<0.01$, whereas the Chla:C ratio of the chlorophyll maximum layer,

\begin{tabular}{|c|c|c|c|c|c|c|}
\hline \multicolumn{7}{|l|}{ Cultures: } \\
\hline Day length & & 24 & & & 12 & \\
\hline$\mu \mathrm{mol} \mathrm{m} \mathrm{m}^{-2} \mathbf{s}^{-1}$ & 400 & & 25 & 400 & & 25 \\
\hline Chla:C & 0.013 & & 0.043 & 0.031 & & 0.049 \\
\hline$P_{m}^{C}$ & 0.025 & & 0.033 & 0.047 & & 0.037 \\
\hline \multicolumn{7}{|l|}{ Barents Sea: } \\
\hline Depth, m & $0-20$ & & $30-60$ & $>70$ & & \\
\hline Chla:C & 0.013 & & 0.021 & 0.031 & & \\
\hline$P_{m}^{C}$ & 0.021 & & 0.027 & 0.028 & & \\
\hline
\end{tabular}
which is a few metres thick and is situated between 25 and $65 \mathrm{~m}$ depth. may have ratios $>0.025$. Same data set as in Table 1 . 
For some Barents Sea diatoms (Table 1 ), ${ }^{\mathrm{g}} \phi_{\max }$ is on the average $0.04 \mathrm{~g}$-at $\mathrm{C}$ (mol photons) ${ }^{-1}$. Equation 8 and its counterpart based on equation 3 may also be written in terms of carbon-normalised coefficients; then the changed coefficients ( $\mathrm{q}$ and ${ }^{\circ} \sigma$ or $\alpha^{B}$ and $\mathrm{P}_{\mathrm{m}}^{\mathrm{B}}$, respectively) will necessarily include the variations of the Chla:C ratio. Such equations would be mathematically equivalent to equation 7 of Kiefer \& Cullen (1991 this volume). At very high latitudes, where a light on/ light off cycle may be hard to define, precision may be improved by replacing the product $\mathrm{D} \cdot \mathrm{g}^{\mathrm{C}}$ with summation of hourly estimates for $\mathrm{BPC}^{\mathrm{C}}$.

In conjunction with an earlier version of this model (Sakshaug et al. 1989), it was suggested that irradiance-dependent variation in photosynthetic coefficients might be neglected with little loss of precision. Data for Arctic diatoms (Table 1), however, suggest that irradiancedependent variations in ${ }^{\circ} \mathrm{F}$ and the product $\mathrm{q} \tau$ should not be entirely neglected. Variability in ${ }^{\circ} \mathrm{F}$, and thus ${ }^{\mathrm{B}} \alpha^{\mathrm{B}}$, strongly affects predictions of carbon uptake for low light, whereas variability in $\mathrm{q} \tau$, and thus $\mathbf{B P}_{\mathrm{m}}^{\mathrm{B}}$, affects predictions for high light strongly. The use of properly chosen constants, however, is certainly more convenient than the use of variables and should be adequate for most practical purposes.

Because of practical difficulties in measuring the Chla: $\mathrm{C}$ ratio in the field, other equations than equation 8 may be more convenient. Substitution of the Chla concentration for the Chla:C ratio may yield gross daily particulate production of carbon instead of gross growth rate (Cullen 1990). Empirical functions without the $\mathrm{Chl} a$ :C ratio may also be developed, albeit at a price of less generality. Because $P_{m}^{C}$ varies less with irradiance than $\mathrm{P}_{\mathrm{m}}^{\mathrm{B}}$ and the Chla:C ratio individually (Table 2) and the growth rate of diatoms appears to be related to day length by half saturation kinetics (Gilstad \& Sakshaug 1990), the gross growth rate may be modelled:

$$
\begin{aligned}
& \mu+r=(\mu+r)_{\max }\left[D /\left(K_{D}+D\right)\right] \\
& \quad \times\left[1-\exp \left(-E_{o} / I_{k}\right)\right]
\end{aligned}
$$

where $(\mu+r)_{\max }$ is the asymptotic maximum gross growth rate $\left(d^{-1}\right)$, and $K_{D}$ is the half saturation constant for day length $(D, h)$. For the ten Barents Sea diatom species studied by Gilstad \& Sakshaug (1990), $(\mu+r)_{\max }$ was $0.75 \mathrm{~d}^{-1}$ ( $\mathrm{r}$ assumed to be $\left.0.05 \mathrm{~d}^{-1}\right), \mathrm{K}_{\mathrm{D}} 12.4 \mathrm{~h}$ and $\mathrm{I}_{\mathrm{k}} 20 \mu \mathrm{mol} \mathrm{m}^{-2} \mathrm{~s}^{-1}$ ("white light"; Fig. 10). This set of coefficients is

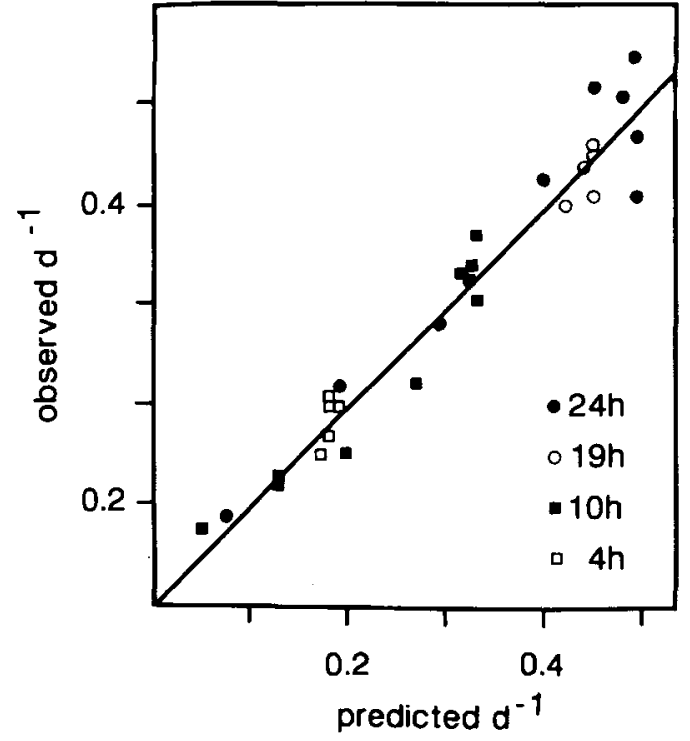

Fig. 10. Predicted (equation 8) versus observed average gross growth rates for 10 Barents Sea diatoms grown at different irradiances $\left(3-500 \mu \mathrm{mol} \mathrm{m} \mathrm{m}^{-2} \mathrm{~s}^{-1}\right)$ and day lengths $(4-24 \mathrm{~h})$ and $-0.5^{\circ} \mathrm{C}$. Standard deviation: $0.035 \mathrm{~d}^{-1}$. Based on data from Gilstad \& Sakshaug (1990).

valid only for nutrient-saturated cells at $-0.5^{\circ} \mathrm{C}$ (no photoinhibition assumed), and may serve as a useful guideline for light-limited gross growth rates of phytoplankton in polar waters.

\section{Photoinhibition}

Photoinhibition may be defined as a lowered photosynthetic or growth rate when light becomes strong. On the basis of equation 8 , it is evident that photoinhibition of growth can be mediated through an increase in the respiration rate, a decrease in the Chla: $\mathrm{C}$ ratio, a change in the photosynthetic coefficients of a combination of these.

Strong light does inhibit growth of polar phytoplankton. In a culture of Antarctic pennate iceedge diatoms, the growth rate dropped from 0.25 to $0.19 \mathrm{~d}^{-1}$ for an increase in irradiance from 104 to $990 \mu \mathrm{mol} \mathrm{m}{ }^{-2} \mathrm{~s}^{-1}$ (Sakshaug \& Holm-Hansen 1986). The growth rate of a culture of Thalassiosira bioculata from the Barents Sea dropped from 0.47 to $0.36 \mathrm{~d}^{-1}$ for an increase from 230 to $430 \mu \mathrm{mol} \mathrm{m}^{-2} \mathrm{~s}^{-1}$ (Sakshaug 1989). The Chla:C ratio, however, dropped relatively more: from 
0.010 down to 0.0040 and from 0.021 down to $0.013 \mathrm{mg} \mathrm{mg}^{-1}$. respectively. This implies that inhibition of growth has been mediated by a decrease in the Chla:C ratio and that ${ }^{\mathrm{E}} \mathrm{P}^{\mathrm{B}}$ (and thus ${ }^{\mathrm{P}} \mathrm{P}_{\mathrm{m}}^{\mathrm{B}}$ ) may, in contrast, have increased.

Photoinhibition in terms of Chla-normalised photosynthetic coefficients appears to be likely only during short-term exposure to strong light. e.g. before the cellular concentration of photoprotective pigments has had time to build up (Lewis \& Smith 1983) or if the ability to build up high concentrations is lacking, which is highly species-dependent (Sakshaug et al. 1987). Inhibition may occur when populations in vertically mixed waters are briefly exposed to the illumination near the surface, and shade-adapted populations appear to be more susceptible than lightadapted populations (Platt et al. 1982).

Short-term photoinhibition is usually described by the empirical P-I formulation of Platt et al. (1980).

$$
\begin{aligned}
& \mathrm{P}^{\mathrm{B}}=\mathrm{P}_{\mathrm{s}}^{\mathrm{B}}\left[1-\exp \left(-\alpha^{\mathrm{B}} \mathrm{E}_{\mathrm{o}} / \mathrm{P}_{\mathrm{s}}^{\mathrm{B}}\right)\right] \\
& \quad \times \exp \left(-\beta^{\mathrm{B}} \mathrm{E}_{\mathrm{o}} / \mathrm{P}_{\mathrm{s}}^{\mathrm{B}}\right) .
\end{aligned}
$$

$\mathrm{P}_{\mathrm{s}}^{\mathrm{B}}$ represents the potential maximum carbon uptake (same units as $\mathrm{P}_{\mathrm{m}}^{\mathrm{B}}$ ) and $\beta^{\mathrm{B}}$ is a photoinhibition coefficient (same units as $\alpha^{\mathrm{B}}$ ). For $\beta^{\mathrm{B}}=$ 0 , this function is equal to equation 3. $\beta^{\mathrm{B}}$ is highly variable in polar phytoplankton: reported values range from about zero to 0.021 [see Smith \& Sakshaug (1990), for review]. The majority of values however, are $<0.0003$. This implies a reduction in $\mathrm{P}^{\mathrm{B}}$ of $<24 \%$ relative to $\mathrm{P}_{\mathrm{s}}^{\mathrm{B}}$ at $1000 \mu \mathrm{mol} \mathrm{m} \mathrm{m}^{-2} \mathrm{~s}^{-1}$.

Because irradiance (PAR) at $0.5 \mathrm{~m}$ depth is not higher than $1000-1500 \mu \mathrm{mol} \mathrm{m} \mathrm{m}^{-2} \mathrm{~s}^{-1}$ at 63 $74^{\circ}$ latitude and the weather is frequently cloudy (Hegseth \& Sakshaug 1983; B. G. Mitchell. unpubl. data), photoinhibition of the growth rate as well as of the short-term photosynthetic response should be of little significance in polar regions and certainly in terms of depth-integrated production.

The major effect of photoinhibition may be related to the distribution of species. Whereas polar species apparently grow well in strong light and long days in combination with low temperature. a majority of temperate species do not (E. Sakshaug \& K. Tangen unpubl. data). In essence. photoinhibition of growth in temperate species becomes more pronounced with decreasing temperature (Talling 1957). Thus, many temperate species may have an over-summering problem in cold waters due to strong light, whereas polar phytoplankton may have an oversummering problem in temperate waters because of high temperature.

\section{Relative importance of environmental variables}

To evaluate the relative importance of optically relevant parameters for the development of spring blooms, we have run mathematical simulations of the early phase of the bloom. We have assumed an infinite vertical mixing coefficient in the windmixed (homogeneous) layer and have included the effect of latitude, date and spectral distribution of light in the atmosphere (Bird 1984) and water, including self-shading by algae (see Appendix). Two latitudes, 63 and $74^{\circ} \mathrm{N}$, and two types of water, "blue" and "green" (Fig. 4), have been chosen. Algal coefficients represent shadeadapted large-celled centric diatoms.

The model demonstrates the importance of the depth of the mixed layer for the progress of the spring bloom (Figs. 11, 12). In fact, depths of mixing of $150-200 \mathrm{~m}$, which may not be infrequent in deep polar seas in winter, early spring or late autumn (Holm-Hansen et al. 1977; Blindheim 1989; Loeng 1989), would preclude blooms large enough to exhaust the mixed layer of winter nutrients in any polar sea. To exhaust the large nutrient concentrations in Antarctic waters, depths of mixing would have to be $<10 \mathrm{~m}$ (Kocmur et al. 1991; Sakshaug et al. 1991b).

Another important factor is the optical quality of the water. Because of the strong attenuation of blue light in green coastal waters, the Chla concentration would surpass $1 \mathrm{mg} \mathrm{m}^{-3}$ about 60 days later in green than in blue water for a mixing depth of $40 \mathrm{~m}$ (compare Fig. 11B with Fig. 12A).

A cloud cover which attenuates light by $70 \%$, which may be a realistic average for the atmospheric "low-pressure" belt, may delay a bloom by at least 20 days and progressively more the deeper the mixing (Fig. 11B-D). Moreover, a bloom develops later at a high rather than a low latitude by at least 20 days, depending on the depth of mixing. On the other hand, the delay at high latitudes is in part compensated for by the faster development of the bloom due to the more rapid increase in incident light at high latitudes (Fig. 12B-D). 
Because measurements of light and light absorption by algae at the spectral level (PUR) require expensive instrumentation and a large amount of data processing relative to measurements in terms of PAR, we have evaluated the extent to which the two approaches yield different results. The PUR approach takes into consideration the spectral variation in light with depth (variable ${ }^{\mathrm{g}} \alpha^{\mathrm{B}}$ ), whereas the PAR approach is based on total irradiance $(400-700 \mathrm{~nm})$ and a constant ${ }^{g} \alpha^{\mathrm{B}}$ derived on the basis of "white" halogen lamp incubator illumination (Fig. 9). In green water (Fig. 12), the difference between the PUR and PAR predictions is small, because $\alpha^{B}$ in the upper layers is not very different from the laboratory estimate. For blue waters, the difference is considerable because of the generally higher value of $\alpha^{B}$ relative to the incubator value (Fig. 11B-C). In both cases, precise knowledge of $\alpha^{B}$ and ambient irradiance at the spectral level becomes increasingly important the deeper the mixing because the average photosynthetic rate in the column will increasingly be determined by the spectrally dependent part of the P-I curve near the origin. Consequently, spectral information is particularly important in the case of deeply mixed oceanic waters.

The model clearly shows that the progress of
Fig. 11. Progress of spring bloom in "clearest" ocean water as a function of the depth $(m)$ of the mixed layer. A: $74^{\circ} \mathrm{N}$ ("Barents Sea"); BD: $63^{\circ} \mathrm{N}$ ("Norwegian Sea"). Incident light according to Bird (1984) except for D (70\% reduction). For the Southern Hemisphere the time scale should read AugustDecember. For further explanation, see text and Appendix.

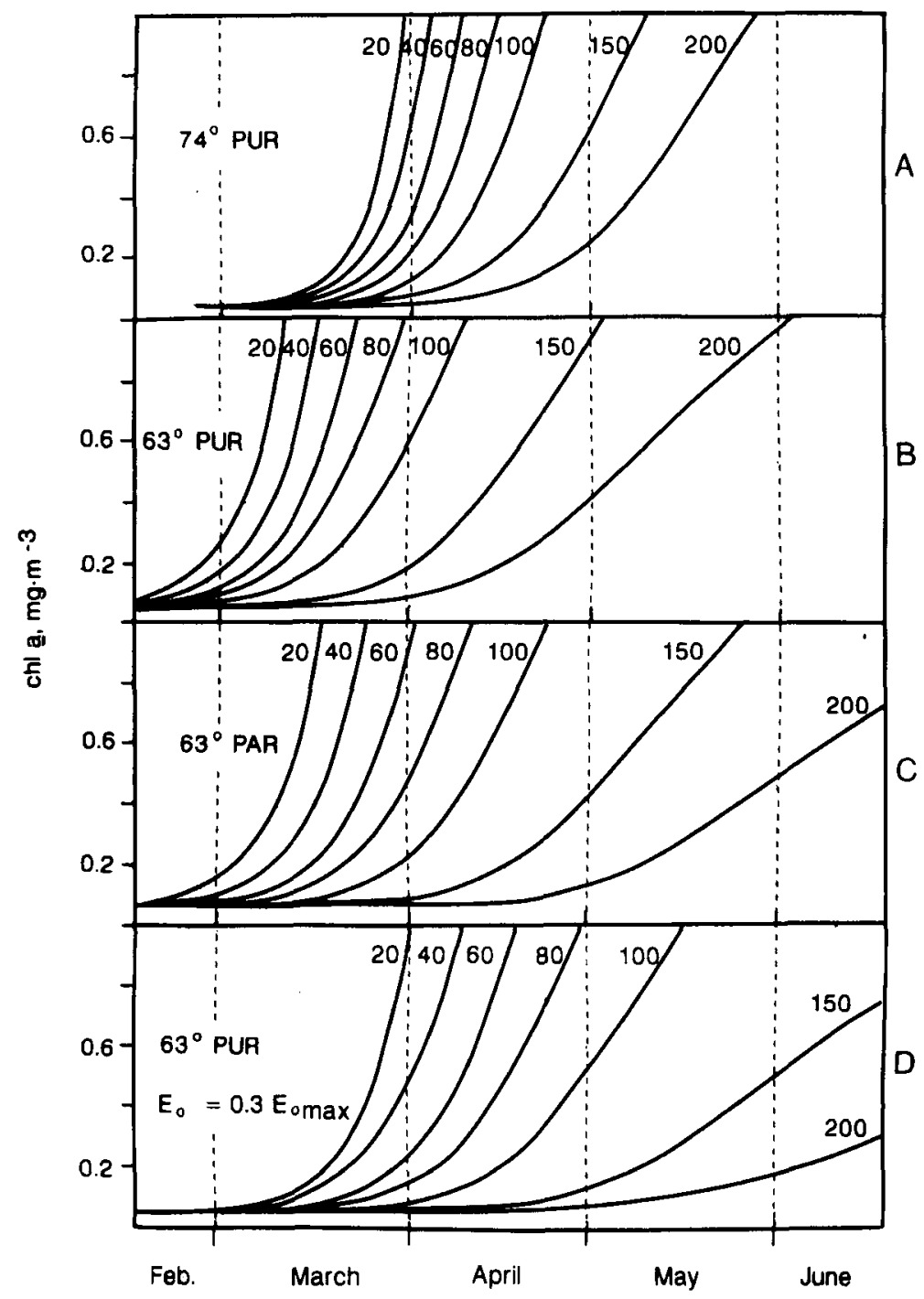




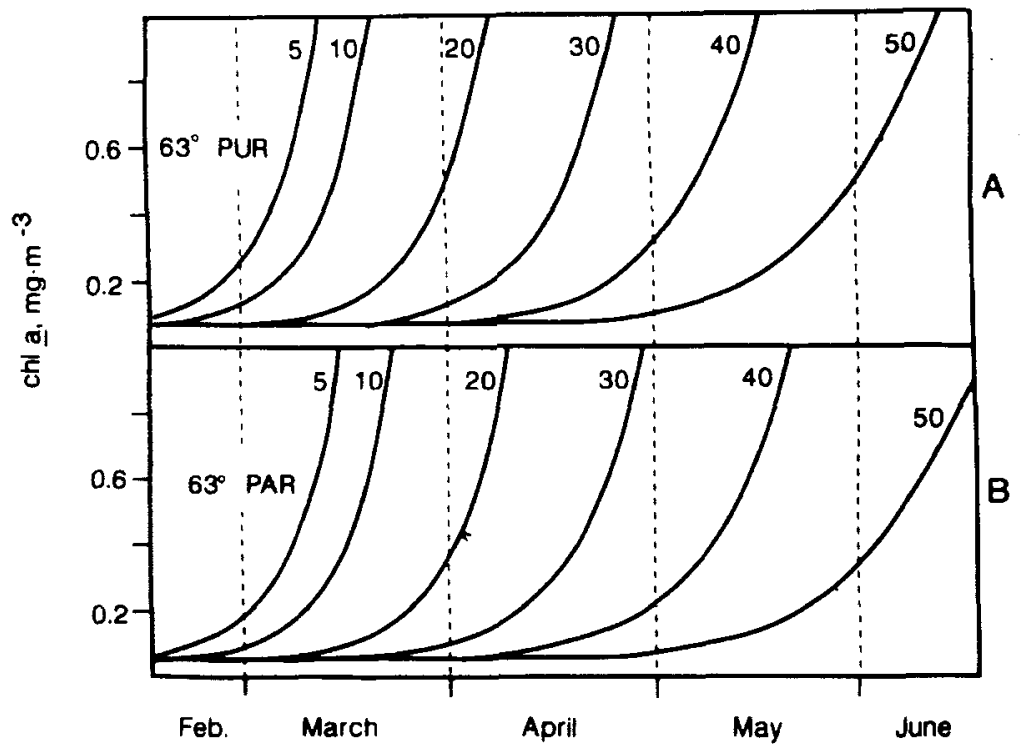

Fig. 12. Progress of spring bloom in "clearest" green water at $63^{\circ} \mathrm{N}$ ("Trondheimsfjorden") as a function of the depth of the mixed layer $(\mathrm{m})$. For the Southern Hemisphere the time scale should read AugustDecember. For further explanation, see text and Appendix. the spring bloom is most sensitive to small changes in the light regime when mixing is deep, i.e. the average irradiance in the mixed column is small. In photosynthetically inefficient regimes such as green coastal waters. the sensitivity of the model is large even at moderate mixing depths. Although phytoplankton stocks may be fairly precisely modelled on the basis of crude average values for environmental variables when mixing is shallow, every factor plays an important role when mixing is deep. By "deep" is meant more than $20 \mathrm{~m}$ and $80 \mathrm{~m}$ in green and blue waters, respectively. Thus the development of phytoplankton biomass in marginal light regimes may be most difficult to model realistically.

The model indicates that blue ocean waters have a potential for allowing blooms in early March in the Northern Hemisphere (or early September in the Southern Hemisphere), provided there is shallow vertical mixing. Vertical mixing, however, is simply not shallow enough so early in the season because thermal stratification is out of the question. making meltwater from sea ice the only stabilizing agent. Sea ice may start to melt in April (October in the Southern Hemisphere), but usually does not melt appreciably until May in the Northern Hemisphere and November in the Southern Hemisphere (Zwally et al. 1983; Parkinson et al. 1987).

If problems related to estimating mixing rate and depth can be adequately solved, it should be possible to predict gross photosynthesis in the field in crude terms by means of optical data and relatively simple mathematical models. However, the increase in the phytoplankton stock is also very sensitive to variations in loss rates (sedimentation, grazing). Moreover, exponential increase in phytoplankton blooms makes them sensitive to the size of the initial stock (Sakshaug et al. 1991b). Initial stocks in permanently open waters may, for example, be much smaller than the relatively large seeding stocks which may be derived from melting ice. Therefore blooms may develop considerably later in ice-free deep waters than in the zone of melting ice.

Acknowledgements. - This work, which is part of the Norwegian Research Program for Marinc Arctic Ecology (Pro Mare), was financed by the Norwegian Fisheries Research Council and the Norwegian Research Council for Science and the Humanities. We would like to thank G. B. Mitchell and M. Vernet (Scripps Institution of Oceanography, La Jolla), F. Rey (Institute of Marine Research. Bergen). and G. Johnsen (Trondhjem Biological Station) for providing unpublished data. We also thank $K$. Andresen for producing the figures and two referees for most helpful suggestions. Contribution 248. Trondhjem Biological Station.

\section{References}

Alexander. V. 1980: Interrelationship between seasonal sea ice and biological regimes. Cold Regions Sci. Technol. 2, 157178

Arnold. W. 1932: Kinetics of photosynthesis in Chlorella. Cold Spring Harbor Symp. Quantitative Biol. 3, 124-127. 
Bannister, T. T. \& Laws, E. A. 1980: Modeling phytoplankton carbon metabolism. Pp. 243-258 in Falkowski, P. G. (ed.): Primary Productivity in the Sea. Plenum, New York.

Berner, T., Dubinsky, Z., Wyman, K. \& Falkowski, P. G. 1989: Photoadaptation and the package effect in Dunaliella tertiolecta (Chlorophyceae). J. Phycol. 25, 70-78.

Bird, R. E. 1984: A simple, solar spectral model for directnormal and diffuse horizontal irradiance. Solar Energy 32, 461-471.

Blindheim, J. 1989: Ecological features of the Norwegian Sea. Pp. 366-401 in Rey, L. \& Alexander, V. (eds.): Proc. 6th Conf. Com. Arc. Int., 13-15 May 1985. E. J. Brill, Leiden.

Bodungen, B. von, Smetacek, V., Tilzer, M. M. \& Zeitzschel, B. 1986: Primary production and sedimentation during spring in the Antarctic Peninsula region. Deep-Sea Res. 33, 177194.

Braarud, T. 1935: The "Øst" expedition to the Denmark Strait 1929. 11. Phytoplankton and its conditions of growth. Hualrád. Skr. 10, 1-173.

Braarud, T. \& Klem, A. 1931: Hydrographical and chemical investigations in the coastal waters off Møre and in the Romsdalsfjord. Hvalrdd. Skr. 1, 1-88.

Bricaud, A., Morel, A. \& Prieur, L. 1983: Optimal efficiency factors of some phytoplankters. Limnol. Oceanogr. 28,816832.

Campbell, J. W. \& Aarup, T. 1989: Photosynthetically available radiation at high latitudes. Limnol. Oceanogr. 34, 1490-1499.

Cullen J. J. 1990: Models of growth and photosynthesis. DeepSea Res. 37, 667-683.

Cullen. J. J. \& Lewis, M. R. 1988: The kinetics of algal photoadaptation in the context of vertical mixing. J. Plankton Res. 10. $1039-1063$.

Dubinsky, Z., Falkowski. P. G. \& Wyman, K. 1986: Light harvesting and utilization by phytoplankton. Plant Cell Physiol. Tokyo 27, 1335-1349.

Eppley, R. W. 1972: Temperature and phytoplankton growth in the sea. Fish. Bull. NOAA 70, 1063-1085.

Falkowski, P. G. \& Owens, T. G. 1980: Light-shade adaptation: two strategies in marine phytoplankton. Plant Physiology 66, 592-595.

Gallegos, C. L., Platt, T.. Harrison, W. G. \& Irwin, B. 1983: Photosynthetic parameters of arctic marine phytoplankton: Vertical variations and time scales of adaptation. Limnol. Oceanogr. 28, 698-708.

Gieskes, W. W. C., Veth, C., Woehrmann, A. \& Graefe, M., 1987: Secchi disc visibility world record shattered. Eos 68 , 123.

Gilstad, M \& Sakshaug, E. 1990: Growth rates of ten diatom species from the Barents Sea at different irradiances and day lengths. Mar. Ecol. Prog. Ser. 64, 169-173.

Gran, H. H. (1931): On the conditions for the production of plankton in the sea. Rapp. P.-v. Réun. Cons. Int. Explor. Mer 75, 37-46.

Harrison, W. G. \& Platt, T. 1980: Variations in assimilation number of coastal marine phytoplankton: effects of environmental co-variates. J. Plankion Res. 2, 249-260.

Harrison, W. G. \& Platt, T. 1986: Photosynthesis-irradiance relationships in polar and temperate phytoplankton populations. Polar Biol. 5, 153-164.

Hegseth, E. N. 1989; Photoadaptation in marine arctic diatoms. Polar Biol. 9, 479-486.

Hegseth, E. \& Sakshaug, E. 1983: Seasonal variation in lightand temperature-dependent growth of marine planktonic diatoms in in situ dialysis cultures in the Trondhcimsfjord, Norway $\left(63^{\circ}\right.$ N). J. Exp. Mar. Biol. Ecol. 67. 199-220.
Horner, R. 1976: Sea ice organisms. Oceanogr. Mar. Biol. Ann. Rev. 14, 167-182.

Holm-Hansen, O., El Sayed, S. Z., Franceschini, G. A. \& Cuhel, R. L. 1977: Primary production and the factors controlling growth in the Southern Ocean. Pp. 11-50 in Llano, G. A. (ed.): Adaptation within Antarctic Ecosystems. Gulf Publ. Co., Houston, Texas.

Jacques, G. 1983: Some ecophysiological aspects of the Antarctic phytoplankton. Polar Biol. 2, 27-33.

Jassby, A. D. \& Platt, T. 1976: Mathematical formulation of the relationship between photosynthesis and light for phytoplankton. Limnol. Oceanogr. 21, 540-547.

Jerlov, N. G. 1976: Marine Optics. Elsevier, Amsterdam. 231 pp.

Jerlov, N. G. \& Stecmann Nielsen, E. (eds.) 1974: Optical Aspects of Oceanography. Academic Press, New York, 494 pp.

Kiefer, D. A. \& Cullen, J. J. 1991: Phytoplankton growth and light absorption as regulated by light, temperature, and nutrients. Pp, 163-172 in Sakshaug, E., Hopkins, C. C. E. \& Øritsland, N. A. (eds.): Proceedings of the Pro Mare Symposium on Polar Marine Ecology, Trondheim, 12-16 May 1990. Polar Research 10(1).

Kiefer, D. A., Morrow. J. H., Stramski, D. \& Chamberlin, W. S. 1990: An electron transport hypothesis for seasonal changes in the spectral absorption coefficient of particles in the western Sargasso Sea. Eos 71. 97.

Kito, J. T. O. 1975: A theoretical analysis of the contribution of algal cells to the attenuation of light within natural waters. I. General treatment of pigmented cells. New Phytol. 75, 1120.

Kirk, J. T. O. 1985: Light and Photosynthesis in Aquatic Ecosystems. Cambridge University Press, Cambridge. 401 pp.

Kocmur, S. F., Vernet, M. \& Holm-Hansen, O. 1991: RACER: Nutrient depletion by phytoplankton during the 1989 austral spring bloom. Ant. J. U.S. In press.

Kopf, U. Heinze, J. 1984: 2,7-bis(die thylamino)phenazoxonium chloride as a quantum counter for emission measurements between 240 and $700 \mathrm{~nm}$. Anal. Chem. 56, 1931-1935.

Langdon, C. 1988: On the causes of interspecific differences in the growth-irradiance relationship for phytoplankton. II. A general review. J. Plankton Res. 10, 1291-1312.

Legendre, L. Demers, S., Garside, C., Haugen, E. M., Phinney, D. A. Shapiro, L. P., Therriault, J.-C. \& Yentsch, C. M. 1988: Circadian photosynthetic activity of natural marine phytoplankton isolated in a tank. J. Plankton Res. 10. $1-6$.

Leverenz, J. W. 1988: The effects of illumination sequence, $\mathrm{CO}_{2}$ concentration, temperature and acclimation on the convexity of the photosynthetic light response curve. Physiol. Plant. 74, 332-341.

Lewis, M. R. \& Smith, J.-C. 1983: A small volume, shortincubation time method for measurement of photosynthesis as a function of incident irradiance. Mar. Ecol. Prog. Ser. 13, 99-102.

Lewis, M. R., Warnock, R. E., Irwin, B. \& Platt, T. 1985: Measuring photosynthetic action spectra of natural phytoplankton populations. J. Phycol. 21, 310-315.

Ley, A. C. \& Mauzerall, D. 1982: Absolute absorption cross sections for photosystem II and the minimum quantum requirement for photosynthesis in Chlorella vulgaris. Biochim. Biophys. Acta 680, 95-106.

Loeng, H. 1989: Ecological features of the Barents Sea. Pp. 327-365 in Rey, L. \& Alexander, V. (eds.): Proc. 6th Conf. Com. Arct. Int., 13-15 May 1985. E. J. Brill, Leiden. 
Maske. H. \& Haardt. H. H. 1987: Ouantitatic in vito absorption spectra of phytoplankton: Detrital ahsorption and comparison with fluorescence excitation spectra Limnol Oceanogr. 32. 6201-633.

Maykut. G. A. \& Grenfell. T. C. 1975: The spectral distribution of light beneath first-year sea ice in the Arctic Ocean. Limnol. Oceanogr. 20, 554-56.3.

Mitchell, G. B. \& Kiefer. D. A. 1988: Chlorophyll a-specific absorption and fuorescence excitation spectra for light-lim. ited phytoplankton. Deep-Sea Res. 35, 639-663.

Morel. A. 1978: Avalable. usable and radiant energy in relation to marine photosynthesis. Deep-Sea Res. 25. 673-688.

Morcl. A. 1988: Optical modeling of the upper ocean in relation to its biogenous matter content (case I waters). J. Geophws. Res. 93 (C9), 10749-117768

Morrow. J. H. Chamberlin. W. S. \& Kiefer. D. A. 1989: A two-component deseription of spectral absorption by marine particles. Limnol. Oceanogr. 34, 150(1)-15099

Myers, J. \& Graham. J-R. 1971: The photosynthetic unit of Chlorella measured by repetitive short flashes. Plant Phvsiol. 48. $282-286$

Nemoto, T. \& Harrison, H. G. 1981: High latitude ccosystems. Pp. 95-126 in Longhurst. A. R. (cd.): Analysis of Marme Ecosystems. Academic Press. New York

Neori. A. \& Holm-Hansen, O. 1982: Effect of temperature on rate of photosynthesis in Antarctic phytoplankton. Polar Biol. 1. 33-3x

Neori, A. Vernet, M. Holm-Hansen. O.\& Haxo, F. T. 1988: Comparison of chlorophyll far-red and red fluorescence excitation spectra with photosynthetic oxygen action spectra for photosystem II in algac. Mar. Ecol. Prog. Ser. 44. 297-302.

Palmisano, A. C. SooHoo. J. B.. Moe. R. L. \& Sullivan. C. W. 1986: Sea icc microbial communitics VII. Changes in under-ice spectral irradiance during the development of antarctic sea ice microalgal communitics. Mar. Ecol. Prog. Ser. 35. 165-173

Parkinson. C. L.. Comiso. J. C.. Zwally. H. J., Cavalieri. D J., Gloersen. P. \& Campbell. W. J. 1987: Arcic Sea Ice. 1973-1976: Satellire Passive-Microwave Observations. NASA SP-489. Scientific and Technical Information Branch, Washington, D.C. $296 \mathrm{pp}$.

Platt. T. \& Subba Rao. D. V. 1975: Primary production of marine microphytes. Pp. 244280 in Cooper. J P. (cd.): Photosinthesis and Productivin in Different Environments. Cambridge University Press. Cambridge.

Platt. T.. Gallegos. C. L. \& Harrison. W. G. 1980: Photoinhibition of photosynthesis in natural assemblages of marine phytoplankton J. Mar. Res. 38. 687-701.

Platt. T. . Harrison. W. G.. Irwin. B.. Horne. E. P. \& Gallegos. C. L. 1982: Photosynthesis and photoadaptation of marine phytoplankton in the Arctic. Deep-Sea Res. 29. 1159-1170.

Post. A. F. Dubinsky. Z. Wyman. K. \& Falkowski. P. G. 1984: Kinetics of light-intensity adaptation in a marine plankton diatom. Mar. Biol. 83, 231-238

Riley. G. A. 1942: The relationship of vertical turbulence and spring diatom flowerings. J Mar. Res. 5. 67-87.

Rilcy. G. A. 1946: Factors controlling phytoplankion populations on Georges Bank. J. Mar. Res. 6. 54-73.

Rochet. M.. Legendre, L. \& Demers. S. 1986: Photosynthetic and pigment responses of sea-ice microaigae to changes in light intensity and quality. J. Exp. Mar. Biol. Ecol. 101. 211226 .

Sakshaug. E. 1989: The physiological ccology of polar phyroplankion. Pp. 61-89 in Rcy. L. \& Alexander. V. (cds.): Proc. oth Conf. Com. Arci Int .13-15 Mar 1985. E. J. Brill, Leiden.
Sakshaug. E. \& Andresen. K. 1986: Effect of light regime upon the growth rate and chemical composition of a clone of Skeletonema costatum from the Trondheimsfjord. J. Plankton Res. 8. 619-637.

Sakshaug. E. \& Holm-Hansen. O. 1984: Factors governing pelagic production in polar occans. Pp. 1-18 in Holm-Hansen, O.. Bolis. L. \& Gilles. R. (cds.): Marine Phytoplankton and Productivity Springer, Berlin

Sakshaug. E. \& Holm-Hansen, O. 1986: Photoadaptation in Antarctic phytoplankton: Variations in growth rate, chemical composition. and P vs I curves. J. Plankton Res. 8. 459473

Sakshaug. E.. Demers. S. \& Yentsch. C. M. 1987: Thalassiosira oceanica and $T$. pseudonana: Two different photoad. aptational responses. Mar. Ecol. Prog. Ser. 41. 275-282.

Sakshaug. E.. Andresen. K. \& Kiefer. D. A. 1989: A steady state description of growth and light absorption in the marine planktonic diatom Skeletonema costatum. Limnol. Oceanogr. 34. 198-2015.

Sakshaug. E. Johnsen. G.. Andresen. K. \& Vernet, M. 1991a: Modeling of light-dependent algal photosynthesis and growth: Experiments with the Barents Sea diatoms Thalassiosira nordenskioeldii and Chaetoceros furcellatus. Deep. Sea Res. 38. 415-430.

Sakshaug. E. Slagstad. D. \& Holm-Hansen. O. 1991b: Factors controlling the development of phytoplankton blooms in the Antarctic Ocean - a mathematical model. Mar. Chem. In press

Sathyendranath. S. \& Platt. T. 1989: Computation of ayuatic primary production: Extended formalism to include effect of angular and spectral distribution of light. Limnol. Oceanogr. 34. $188-198$

Smetacek. V.\& Passow, U. 1990); Spring bloom initiation and Sverdrup's critical-depth model. Limnol. Oceanogr. 35, 228233

Smith. R. C. \& Baker. K. S. 1981: Optical propertics of the clearest natural waters $(200)-800 \mathrm{~nm})$. Appl. Optics 20, 177184

Smith. R. C.. Marra. J., Pcrry. M. J.. Baker. K. S. . Swift. E.. Buskey. E. \& Kiefer. D. A. 1989: Estimation of a photon budget for the upper ocean in the Sargasso Sea. Limnol. Oceanogr. 34. 1673-1693.

Smith. W. O. \& Sakshaug. E. 1990: Polar phytoplankton. Pp. \$77-525 In Smith. W. O.: Polar Oceanography. Part B: Chemistry. Biology and Geology. Academic Press. New York.

SooHoo, J. B.. Palmisano. A. C.. Kottmeier, S. T., Lizotte, M. P. SooHoo, S. L. \& Sultivan. C. W. 1987: Spectral light absorption and quantum yicld of photosynthesis in sea ice microalgac and a bloom of Phaeocystis pouchetii from McMurdo Sound. Antarctica. Mar. Ecol. Prog. Ser. 39. 175 189

Spics. A. 1987: Growth rates of antarctic marine phytoplankton in the Weddell Sea. Mar. Ecol. Prog. Ser. 41. 267-274.

Subba Rao. D. V. \& Platt. T. 1984: Primary production of arctic waters. Polar Biol. 3, 191-201.

Sverdrup. H. U. 1953: On conditions for the vernal blooming of phytoplankton. J. Cons. Perm. Int. Explor. Mer 18. 287295

Talling. J. F. 1957: Photosynthetic characteristics of some freshwater plankton diatoms in relation to underwater radiation. New Phvtol. 56, 29-50.

Tilzer. M. M. \& Dubinsky, Z. 1987: Effects of temperature and day length on the mass balance of antarctic phytoplankton. Polur Biol. 7. 35-42 
Tyler. J. E. (cd.) 1977: Light in the Sea. Dowden. Hutchinson \& Ross. Stroudsburg. Pennsylvania. 384 pp.

Vernet, M., Neori, A. \& Haxo, F. T. 1989: Spectral propertics and photosynthetic action in red-tide populations of Prorocentrum micans and Gonyaulax polyedra. Mar. Biol. 193. 365-371.

Webb, W. L., Newton, M. \& Starr, D. 1974: Carbon' dioxide exchange of Alnus rubra: A mathematical model. Oecologia $17,281-291$.

Weger, H. G., Herzig, R. Falkowski, P. G. \& Turpin, D. H. 1989: Respiratory losses in the light in a marine diatom: Measurements by short-term mass spectrometry. Limnol. Oceanogr. 34, 1153-1161.

Wilson, D. L., Smith, W. O. \& Nelson, D. M. 1986: Phytoplankton bloom dynamics of the western Ross Sea edge. I. Primary productivity and species-specific production. DeepSea Res. 33, 1375-1387

Ziemann. D. A.. Conquest, L. D., Bienfang, P. K. \& Kanda. J. 1987: Patterns of primary production and sedimentation during the 1987 spring bloom in Auke Bay, Alaska. Pp. 29194 in A PPRISE annual report. SFOS APP87-100. School of Fisheries and Ocean Sciences, University of Alaska, Fairbanks.

Zwally, H. J., Comiso, J. C., Parkinson, C. L., Campbell. W. J. Carsey, F. D. \& Gloersen, P. 1983: Antarctic Sea Ice. 1973-1976: Satellite Passive-Microwave Observations. NASA SP-459, Scientific and Technical Information Branch. Washington, D.C. $206 \mathrm{pp}$.

\section{Appendix: Formulation of model}

Assuming negligible lateral coefficients, phytoplankton distribution is affected by vertical turbulent mixing and vertical transport as in the 1-D model

$\frac{\partial P}{\partial t}+w \frac{\partial P}{\partial z}-\frac{\partial}{\partial z}\left(K_{2} \frac{\partial P}{\partial z}\right)=f_{\text {bis }}$

where $P(t . z)$ is phytoplankton concentration at depth $z$ and time $t, w$ is vertical (usually sinking) velocity, $K_{z}(z)$ is the vertical turbulent mixing coefficient, and $f_{\text {his }}$ describes net phytoplankton growth. The vertical mixing coefficient is infinite above the depth of mixing and zero elsewhere. For the early phase of the spring bloom, nutrient limitation is ignored. Thus

$f_{\text {biul }}=P(1, z)\left\{\left[{ }^{z} P^{c}\left(E_{v}(\lambda), 1, z\right)\right]-R\right\}$

where $\left[{ }^{z} P^{C}\left(E_{u}(\lambda), t, z\right)\right]$ is the turnover rate of growth-relevant carbon $\left(\mathrm{h}^{-1}\right)$ as a function of spectral irradiance, time and depth (see equations 6,7 and 8). $\mathrm{R}$ represents in principle the total loss rate, i.e. the sum of dark respiration, sedimentation and grazing rates, but is set at a low value, $0.0046 \mathrm{~h}^{-1}$, which pre- sumably does not significantly cxcecd the dark respiration rate of polar phytoplankton.

Spectral distribution at the sca surface (no clouds) is a function of sun elevation (Bird 1984) and model output is the sum of direct and diffuse irradiance. Water vapour pressure in the atmosphere has been set at $1.42 \mathrm{~cm}$ and turbidity $\tau_{\mathrm{it}}(0.5)$ equals 0.1 . Reflection losses at the surface are set at 5-10\% depending on sun clevation (Kirk 1985).

Spectral distribution of downwelling light is calculated by a model similar to that of Sathyendranath \& Platt (1989): Total downwelling $I(z, \lambda)$ at depth $z$ and wavelength $\lambda$ is partitioned into a dircct component $I_{d}$ and a diffuse component $I_{s}$ :

$\mathbf{I}(z, \lambda)=\mathbf{I}_{\mathrm{d}}(\mathrm{z}, \lambda)+\mathbf{I}_{\mathrm{s}}(\mathrm{z}, \lambda)$.

Vertical attenuation coefficients for diffuse and direct light are given by

$\mathrm{K}_{\mathrm{d}}(\mathrm{z}, \lambda)=\left[\mathrm{a}(\mathrm{z}, \lambda)+\mathrm{b}_{\mathrm{b}}(\mathrm{z}, \lambda)\right] / \cos \theta_{\mathrm{d}}$

and

$K_{s}(z, \lambda)=\left[a(z, \lambda)+b_{b}(z, \lambda)\right\} / \bar{\mu}$

where $a(z, \lambda)$ is the volume absorption coefficient at depth $z$ and wavelength $\lambda$, and $b_{h}(z, \lambda)$ is the corresponding backscattering coefficient. $\theta_{\mathrm{d}}$ is the sun zenith angle in water and $\bar{\mu}$ is the mean cosine of zenith angles of diffuse light $\theta_{\mathrm{s}}$ after refraction at the surface (set at 0.6: Kirk 1985). Multiple scattcring is neglected.

$a(\lambda)$ is the sum of the absorption coefficient of pure water $a_{w}(\lambda)$, either "clearest" blue or "clearest" green water (Fig. 4), and absorption due to particles ${ }^{*} \mathrm{a}_{c} \cdot\left(\mathrm{Chl} a^{*}: \mathrm{C}\right)$. Chl $a^{*}$ is the sum of the Chla concentration and half the concentration of Phaeophytin $a .{ }^{*} \mathrm{a}_{\mathrm{c}}$ is $0.0098 \mathrm{~m}^{2}\left(\mathrm{mg} \mathrm{Chl} a^{*}\right)^{-1}$ in "white" halogen lamp illumination. The Phacophytin a concentration in the Barents Sea is related to Chla according to the function ( $F$. Rey, unpublished data)

Phaco $a=0.45 \mathrm{Chl} a+0.02\left(\mathrm{mg} \mathrm{m}^{-3}\right)$

Algal coefficients are representative for shade-adapted cells of the large-celled centric diatoms Thalassiosira antarctica and $T$. nodenskioeldii (at $25 \mu \mathrm{mol} \mathrm{m}^{-2} \mathrm{~s}^{-1}$ ) using the scaled fiuorescence excitation spectrum ${ }^{\circ} \mathrm{F}$ for ${ }^{\circ} \sigma$ in equations 6 and 8 . ${ }^{\circ} \mathrm{F}$ and ${ }^{\circ} \mathrm{a}$, for white halogen lamp illumination are 0.0058 and $0.0090 \mathrm{~m}^{2}$ (mg Chla $)^{-1}$, respectively. The Chl ratio is $0.052 \mathrm{mg} \mathrm{mg}^{-1}$, ${ }^{g} \phi_{\operatorname{mix}}$ is $0.04 \mathrm{~g}$-at $\mathrm{C}$ (mol photons) ${ }^{-1}$, and the product $q \tau$ is $1370 \mathrm{mg}(\mathrm{mol} \mathrm{PSU})^{-1} \mathrm{~h}$. Thus the growth-relevant values ${ }^{\mathrm{B}} \mathrm{P}_{\mathrm{m}}^{\mathrm{B}}$ and $\mathrm{E}_{\alpha^{8}}^{\mathrm{B}}$ ("white" light) arc $0.35 \mathrm{mg} \mathrm{C}$ ( $\mathrm{mg}$ Chla $)^{-1} \mathrm{~h}^{-1}$ and $0.010 \mathrm{mg} \mathrm{C}(\mathrm{mg} \mathrm{Chla})^{-1} \mathrm{~h}^{-1}\left(\mu \mathrm{mol} \mathrm{m} \mathrm{m}^{-2} \mathrm{~s}^{-1}\right)^{-1}$. respectively. The maximum (light-saturated) gross growth rate is $0.44 \mathrm{~d}^{-1}$.

The equations were solved by a finite difference scheme using a MicroVax computer. The vertical grid point was $5 \mathrm{~m}$ and time step was $1 \mathrm{~h}$. The initial concentration of Chla was $0.05 \mathrm{mg} \mathrm{m}^{-3}$. 
